\title{
A Unified Model of Neoarchean-Proterozoic Convergence and Rifting of Indian Cratons: Geophysical Constraints
}

\author{
Dinesh Chandra Mishra \\ National Geophysical Research Institute (CSIR), Hyderabad, India \\ E-mail:dcm_ngri@yahoo.co.in \\ Received May 6, 2011; revised August 2, 2011; accepted September 18, 2011
}

Abstract

Neoarchean and Proterozoic sutures and collision zones are identified in the Indian Peninsular Shield based on high seismic velocity; gravity highs and high conductivity in the upper crust due to thrusting while subducted side are demarcated based on geophysical signatures of crustal thickening and back arc type basins. Some of them appear to form triple junctions. The Bouguer anomaly map of the south Indian shield when transformed to apparent density map through harmonic inversion, provided high density linear zones coinciding with the shear zone and the transition zone-the Moyar Bhavani Shear Zone (MBSZ) between the Eastern Dharwar Craton (EDC) and the Western Dharwar Craton (WDC) and the Dharwar cratons and the Southern Granulite Terrain (SGT), respectively. It is supported by high seismic velocity and high conductivity suggesting them to be caused by high grade granulite rocks related to Neoarchean-Paleoproterozoic sutures and collision zones. These investigations also suggest thick crust ( 40 - $50 \mathrm{~km})$ under the WDC and the SGT forming crustal root of 50 - $52 \mathrm{~km}$ in the south western part and thin crust of 31 - $32 \mathrm{~km}$ under the EDC indicating direction of convergence and subduction as E-W and N-S between the EDC and the WDC and Dharwar cratons and the SGT, respectively. It gave rise to contemporary lower crustal granulite rocks in the northern part of the SGT and Cauvery shear zone (CSZ) as collision related central core complex of various deep seated intrusive rocks of Paleo-Mesoproterozoic period. The second case belonging to Meso-proterozoic period is related to the collision of the Bundelkhand craton and the Bhandara-Bastar craton (BBC) and the Dharwar craton (DC) in Central India along the Satpura Mobile Belt (SMB) and the BBC and the DC along the Godavari Proterozoic Belt due to N-S and NE-SW convergences, respectively. This process has given rise to lower crustal granulite rocks of high density, high velocity and high conductivity along the SMB and the GPB. An upper mantle conductor delineated south of the western part of the SMB under Deccan Volcanic Province and a regional gravity gradient almost sub parallel to it indicate an interface with fluids separating rocks of different densities that appears to demarcate the trace of the Proterozoic subduction and suture related to the SMB collision zone during Mesoproterozoic period. High reflectivity of the lower crust along seismic profiles across the SMB indicate an extensional phase prior to this convergence. The SMB is connected to the Aravalli Delhi Mobile Belt (ADMB) in the western part that is another collision zone of Meso-proterozoic period, forming an arcuate shaped collision zone between the Bundelkhand craton and Rajasthan block with E-W convergence. There are indications of a prior phase of convergence during Paleo-Proterozoic period followed by rifting during Paleo-Meso-proterozoic period ( 1.9 - 1.6 Ga) along the $\mathrm{SMB}$, the ADMB and the GPB that gave rise to large scale contemporary intrusive in these sections. The contemporary Mahakoshal-Bijawar and Pakhal group of rocks of Paleo Proterozoic period ( 1.9 - 1.6 Ga) were deposited over the rifted platform of the Bundelkhand craton along the SMB and cratons along the GPB, respectively during the extensional phase as suggested above based on high reflectivity of the lower crust. It is followed by deposition of the Vindhyan sediments of Meso-Neoproterozoic period ( 1.6 - $0.7 \mathrm{Ga})$ along the SMB and the ADMB as foreland basins during Meso-Neoproterozoic convergence. Simultaneous N-S and E-W directed convergences in the two cases, viz., the SMB and the ADMB that are connected forming an arcuate shaped collision zone suggest NE-SW directed primary stress direction similar to the GPB that is supported by NW-SE oriented large lineaments in Bundelkhand craton and Peninsular shield. The Eastern Ghat Mobile Belt (EGMB) also shows signatures of E-W or NE-SW directed Mesoproterozoic ( 1.5 - $1.0 \mathrm{Ga})$ 
convergence with East Antarctica. This convergence was preceded by Paleo-Mesoproterozoic rifting ( 1.9 $1.6 \mathrm{Ga}$ ) that gave rise to contemporary activities of the EGMB and large scale volcanic activity that formed several basins west of it.

Keywords: Indian Shield, Convergence, Collision, Triple Junction and Gravity Anomaly

\section{Introduction}

In a Precambrian terrain, if crustal blocks are separated by boundary across which there is a marked difference in physical properties, stratigraphy or tectonic history or a discontinuity in structural trends, such boundaries represent a suture, especially if it is highly sheared. Similarly, there are several geophysical signatures as described below based on the present day collision zones that helps in delineating suture zones in Archean-Proterozoic terrains.

1) Dipping reflectors from either sides in the crust whose junction if projected on surface coincide with a sheared zone and high velocity lower crustal rocks may occur along it.

2) Dipping reflectors in the upper mantle away from the suture showing the trace of the subducted rocks.

3) Paired gravity anomalies of high over Proterozoic terrain representing high density lower crustal rocks and low over the Archean terrain related to sediments of the foreland basins [1,2]. Another low may be observed on the other side of the collision zone [3] due to crustal thickening producing a gravity high flanked by gravity lows on either side.

4) Magnetotelluric surveys invariably provide blocks of different conductivities on either sides of the Archean-Proterozoic suture. It also provides high conductivity at shallow depth on the obducted side (mobile belts) and along the suture that are related to thrusted blocks and fluids. It may also provide inclined interfaces of high conductivity in the upper mantle indicating fluid containing rocks such as serpentines as is shown in Figure 8(b).

A tectonic map of the Indian Peninsular Shield is given in Figure 1 in order to show various fold (mobile) belts like the Aravalli-Delhi (ADMB), the Satpura (SMB) and the Eastern Ghat (EGMB) Mobile Belts with respect to various cratons. This Figure is also used to show the direction of convergence (arrows) between various cratons in one diagram during Precambrian times based on the present study. Detailed geological maps of the various sections of the Indian Shield are given while discussing their geophysical signatures. Mobile belts, shear zones and the transition zones are significant for Archean-Proterozoic tectonics that are discussed below. This paper briefly refers and describes the geophysical data and available models that are supplemented with new data and computed models to provide a comprehensive picture of Neoarchean-Proterzoic convergence and rifting of the Indian cratons.

\section{Bouguer Anomaly Map}

Bouguer anomaly of the Indian Shield is shown in Figure $2[4,5]$ that shows a large wavelength gravity low over the South Indian shield south of the SMB. However, there are several small wave length lows and highs occurring within this large wave length gravity low that are related to sub surface density anomalies. Gravity highs and lows are marked as H1-H22 and L1-L22. Same numbers of highs and lows does not mean that all form paired gravity anomalies that are marked in this manner to locate them easily. However, some of them fall in this category that has been highlighted in discussions below. The gravity highs, $\mathrm{H} 1, \mathrm{H} 2$ and $\mathrm{H} 3$ and $\mathrm{H} 5$ are related to the shear zone between the EDC and the WDC, eastern part of the transition zone (Palar shear) between the EDC and the SGT and the transition zone - the MBSZ between the WDC and the SGT, respectively (Figure 3) that are discussed below.

Similarly gravity highs, H8, $\mathrm{H} 9$ and $\mathrm{H} 10$ and $\mathrm{H} 11$ in Central India represent Satpura Mobile Belt (SMB) and Godavari Proterozoic Belt (GPB), respectively (Figures 2 and 3) that separate Bundelkhand craton towards the north and Bhandara-Bastar craton towards the SE and Dharwar craton towards the SW. They form pairs with gravity lows L8, L9 and L11 that are examined below for their geodynamics significance. The gravity highs H19H21 are related to the Eastern Ghat Mobile Belt (EGMB) that extend towards the south (H18) and the north (H22). In these cases, the gravity highs are observed over the younger Proterozoic fold belts and lows over the adjoining older Archean cratons that have been termed as paired gravity anomalies indicating Proterozoic collision zones as described above and therefore these anomalies along with other geophysical data from these regions are examined below in detail.

\section{South Indian Shield}

A generalized geological map of the South Indian shield is given in Figure 3 that shows primarily the EDC, 


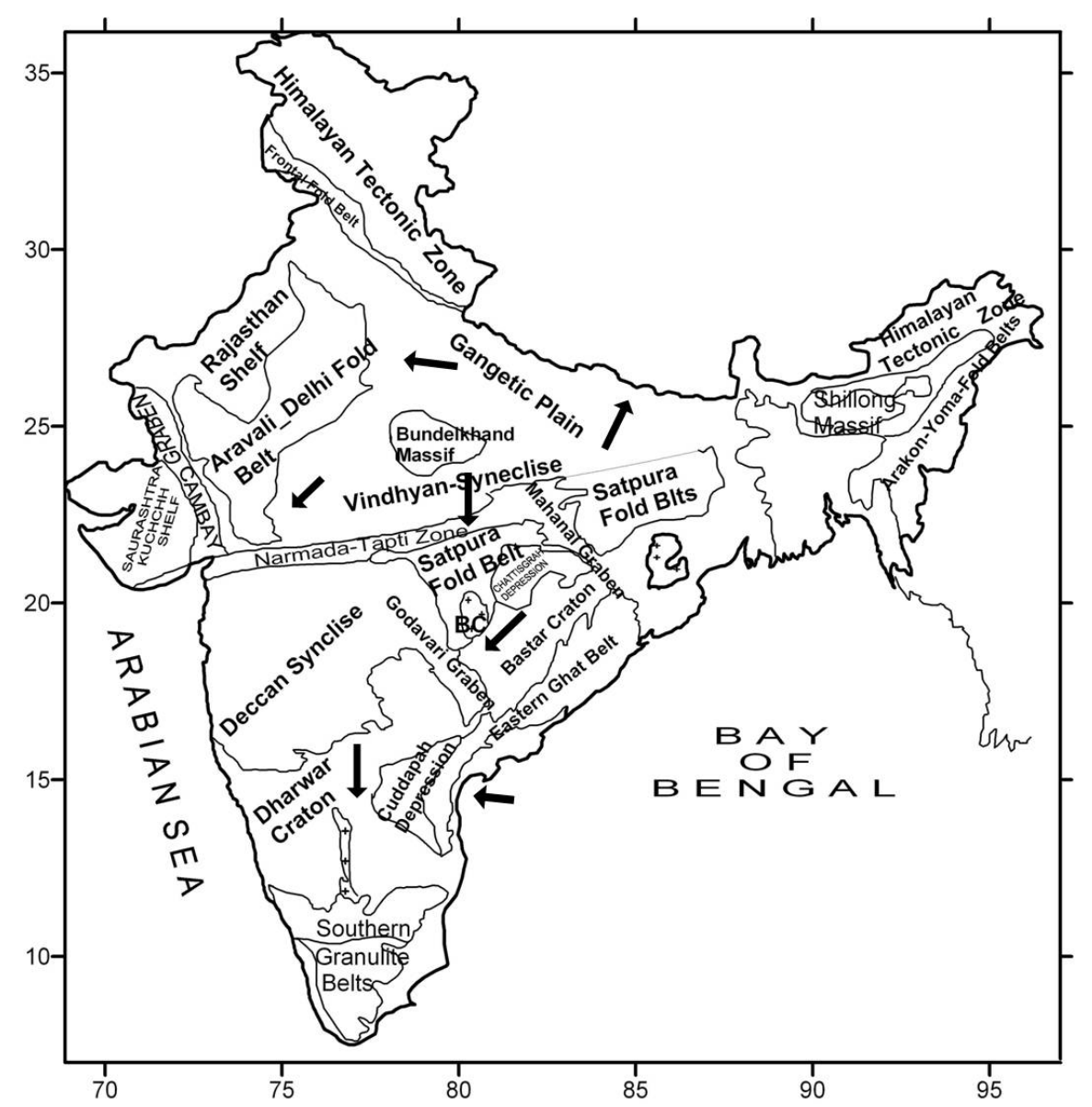

Figure 1. A simplified tectonic map of India showing various cratons and fold (mobile) belts (after ONGC, 1968) with arrows indicating direction of convergence during Proterozoic convergence based on the present study. The SW-NE directed arrow in the north indicates Cenozoic convergence across the Himalayan Fold Belt while NE-SW arrows indicate Neoarchean-Neoproterozoic convergence between various cratons that is opposite to the present day convergence direction and is consistent both in the North and South Indian Shields. There was an intermediate rifting phase during Paleo-Mesoproterozoic period when contemporary basins formed over the rifted platform of the Indian cratons. BC-Bhandara Craton; GPB- Godavari Proterozoic Belt. Sangole-Partur is a profile south of the SMB in Deccan Synclise $\left(\sim 75^{\circ} \mathrm{E}, 17.5^{\circ} \mathrm{N} ; \sim 75^{\circ} \mathrm{E}, 20^{\circ} \mathrm{N}\right)$ shown in Figure 8(b).

the WDC and the SGT and associated shear and transition zones between them. The residual gravity anomaly of the South Indian Shield is obtained by removing regional field using zero free air regional anomalies [6] where Bouguer anomaly would correspond to regional field due to isostasy. This residual anomaly can be converted to apparent density map through Fourier transformation that would represent bulk density distribution in the region [7,8]. The apparent density map (Figure 4) highlights the high density rocks; H1, H2 and $\mathrm{H} 3$ along the shear zone and the eastern part of the transition zone (Palar shear) and the MBSZ between the EDC and the WDC and the EDC and the WDC and the SGT, respectively. They are marked as $\mathrm{H} 1, \mathrm{H} 2$ and $\mathrm{H} 3$ corresponding to the gravity highs, H1, H2 and H3 as given in Figure 2. This map defines a triple junction at Bangaluru with high density sections making almost $120^{\circ}$ from each other indicating a stable triple junction (Mckenzie and Morgan, 1969). These sections of high density rocks are investigated below for Proterozoic collision tectonics.

\subsection{Dharwar Cratons}

As shown in Figure 3 (GSI, 1993), this part is composed of the Eastern and the Western Dharwar Cratons (EDC and WDC). This section is characterized by several gravity anomalies. However gravity highs and lows, H1, L1 and H6-H7 and L6-L7 (Figure 2) are located close to the shear zone between the EDC and the WDC and are therefore significant in regard to their interaction. The gravity anomalies, H17 and L17 (Figure 2) are related to Cuddapah basin (Figure 3) that are dealt below in a separate section under the EGMB. For the first time the geoid data of the Indian Peninsular shield (Figure 5) is 


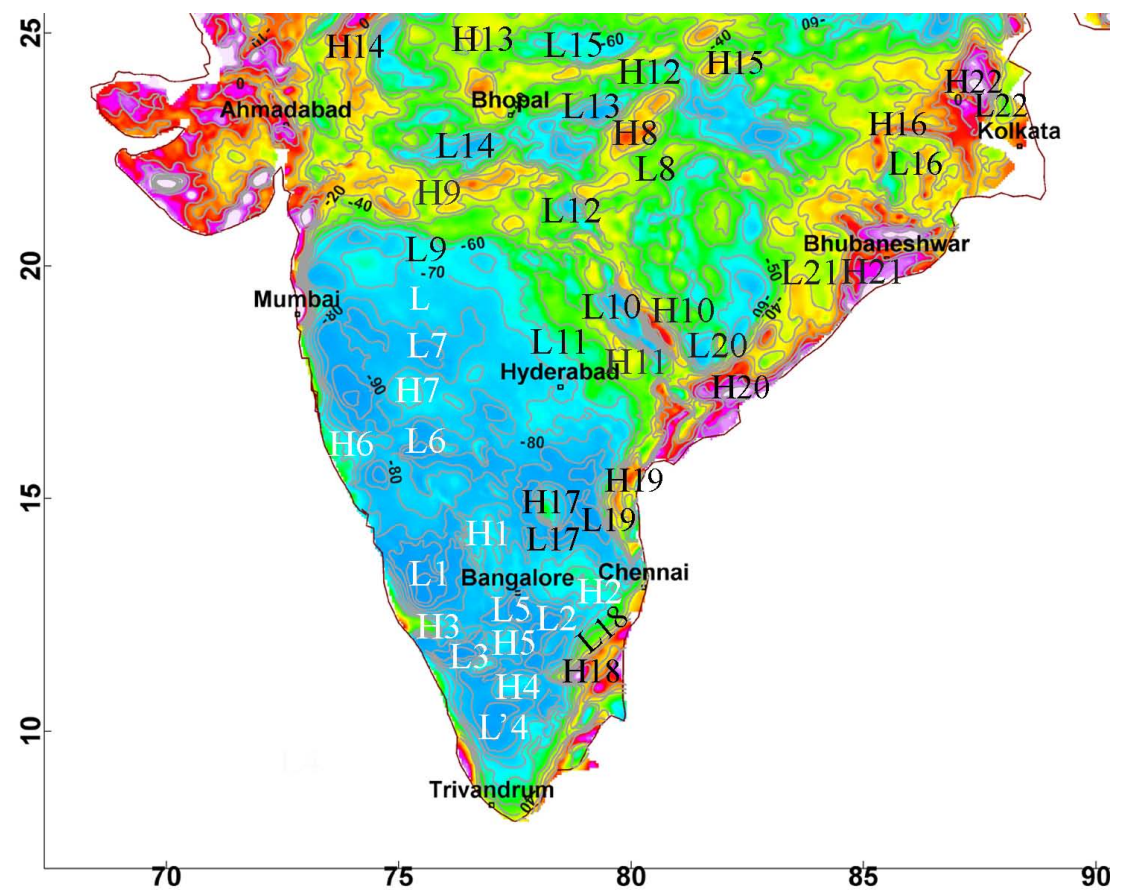

Figure 2. Bouguer anomaly map of south Indian Shield with various gravity highs and lows related to the present study are marked as H1-H22 and L1-L22. White and black numbered anomalies are related to Neoarchean and Proterozoic collision and triple junctions in South Indian and Central Indian Shields and Eastern Ghat fold (mobile) belt respectively. Equal numbers of gravity highs and lows numbered here do not mean that all of them form paired gravity anomalies that has been done here for convenience of reference. However, some of them belong to that category that has been discussed in the text.

integrated with the gravity anomalies and used to infer tectonics of this region.

1) The shear zone (SZ, Figure 3) between the EDC and the WDC separates the two parts of the Dharwar craton which show differences of rock types and structures and therefore considered as a suture of Neoarchean -Paleoproterozoic period. The EDC is characterized mainly of Archean gneisses with linear K-granite plutons and schist belts such as Closepet granite of Neoarchean times [2.6 - $2.5 \mathrm{Ga}, 9]$. Various granitic batholiths of Neoarchean to Paleoproterozoic period of the WDC and the EDC might have formed as subduction related magmatism between the Western and the Eastern Dharwar cratons across the shear zone between them [10]. Chadwick et al. [11] have considered an oblique convergence from the east to the west across this shear zone. The position of shear zone has been a matter of considerable debate among geologists that whether it runs along the eastern margin of the Chitradurga schist belt as shown in Figure 3 or along the eastern or the western margins of the Closepet granite. In fact, it may be a zone between the Chitradurga Schist Belt and the Closepet granite as appatent from the gravity highs, $\mathrm{H} 1$.

2) The WDC is characterized primarily by schist belts (Figure 3) of Meso-Neoarchean period [2.9 - 2.7 Ga, 12]. There are some small exposures of older schist belts of
Mesoarchean time (3.4 - 3.0 Ga) in the southern part of the WDC under parts of the gravity low, L1 (Figure 2). Schist belts primarily consist of mafic and ultramafic rocks with metasediments and granite intrusives along margins such as in case of the Chitradurga schist belt. They usually show gravity highs and lows related to mafic and felsic intrusives and crustal thickening [13].

3) Receiver function analysis has provided crustal thickness of 40 - $55 \mathrm{~km}$ and 31 - $32 \mathrm{~km}$ under the southern part of the WDC and the EDC, respectively [14]. Based on Poissions ratio, they have also suggested a felsic crust under the EDC and mafic crust under the WDC. Gupta et al. [15] based on receiver function analysis provided crustal thickness increasing consistently from 35 $\mathrm{km}$ under Deccan Volcanic Province SE of Mumbai to 50 - $55 \mathrm{~km}$ under the southern part of the WDC and south of the transition zone-Moyar Shear under the Nilgiri hills (SW part of the SGT; Figure 3), that reduces to 43 - $45 \mathrm{~km}$ in the southern and the eastern parts of the SGT south of the PCSZ.

4) The gravity highs, H1 (Figure 2) spreads from east of the Chitradurga schist belt to the Closepet granite and extends from the transition zone towards the south around Bangalore to the N-W up to Panaji (H6) along the west coast of India following structural trends of geological features like Closepet granite, Chitradurga schist 


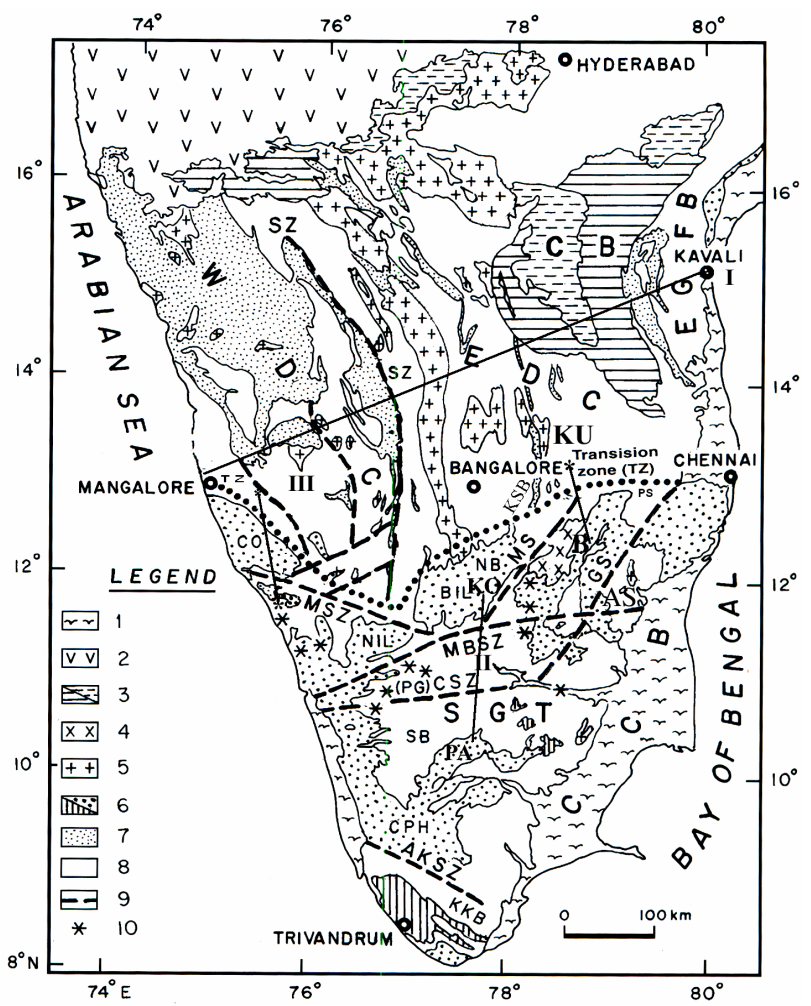

Figure 3. Simplified geological map of south Indian Shield showing the Dharwar craton and the Southern Granulite Terrain (SGT), which is to the south of the Transition zone (TZ). Various abbreviations are as follows: AKSZ-Achankovil shear zone, AS-Attur Shear, BIL-Biligirirangan Hills, CB-Cuddapah basin, CCB-Cauvery coastal basin, CO-Coorg Hills, CPH-Cardoman-Palani Hills, CSZCauvery shear zones, EDC-Eastern Dharwar Craton, EGFB - Eastern Ghat Fold (mobile) Belt, GS-Gangavalli Shear zone, KKB-Kerala Khondalite Block, KSB-Kolar Schist Belt, MS-Mettur Shear, MBSZ-Moyar Bhavani shear zone, NB-Northern Block, NIL-Nilgiri Hills, PCSZPalghat Cauvery shear zone, PG-Palghat gap, SB-Southern Block, SZ - shear zone between EDC and WDC, WDCWestern Dhar-war Craton, PS-Palar Shear. Various geological formations and symbols are as follows: 1-Cretaceous-recent sediments, 2-Cretaceous-Eocene Deccan basalts, 3-Proterozoic metasediments, 4-alkaline complexes and Carbonatites, 5-Granites (Un differentiated), 6 -Charnockites-Granulites/Khondalites, 7-Archaean greenstone belts, 8-Gneisses, 9-Major lineaments/Shear zones and 10-Epicenter of some earthquakes associated with shear zones in the SGT. It also shows Profiles I across Cuddapah basin and Dharwar craton and Profiles II and III across the SGT. KU-Kuppam, B-Bommidi, Ko-Kolattur, PA-Palani Modified after GSI, 1993).

belt etc.

5) Another data set that is important to investigate subsurface density in homogeneity is the geoid data that is primarily suitable for deep seated structures. This whole region is covered by Indian Ocean geoid low (Figure 5,

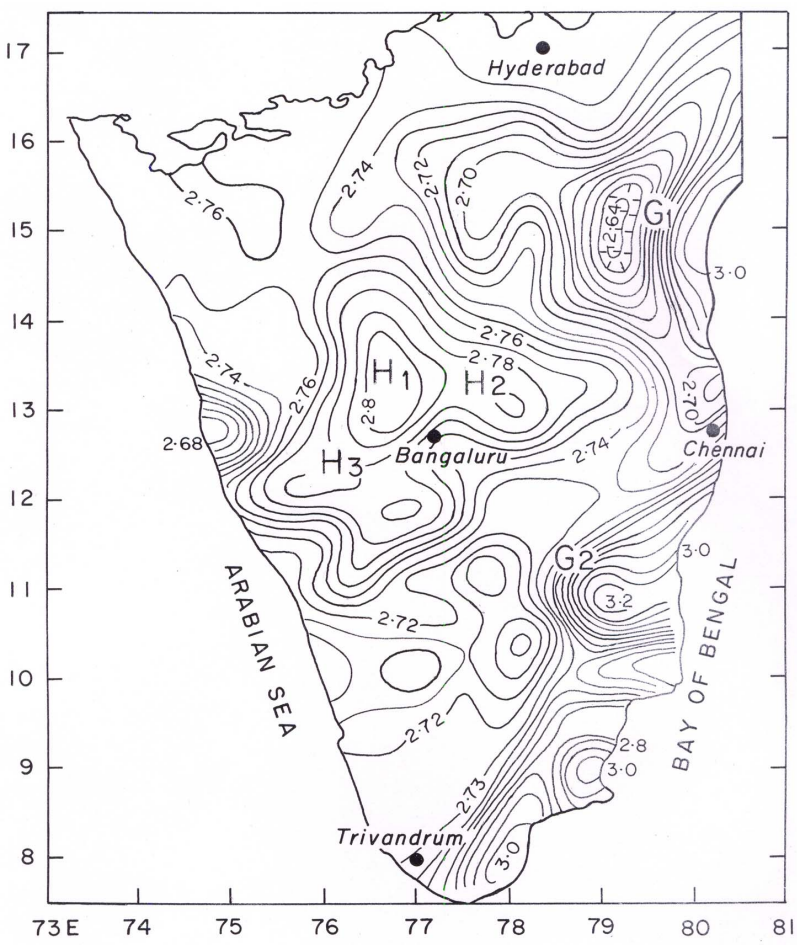

Figure 4. Apparent density map of the South Indian shield obtained from the deconvolution of the residual field that shows three zones of high density $\mathrm{H} 1, \mathrm{H} 2$ and $\mathrm{H} 3$ coinciding with the shear zone between the WDC and the EDC, eastern part of the transition zone (Palar shear) and the MBSZ, respectively. They join around Bangaluru similar to gravity highs (H1-H3) in Figure 2 defining a triple junction.

http://icgem.gfz-potsdam.de/IC-GEM/ICGEM.html) that is related to deep seated density distribution. However, it shows some relative gravity highs, $\mathrm{H} 1-\mathrm{H} 3$ that is quite significant as they are observed with in the regional low. The geoid high, $\mathrm{H} 1$ is most pronounced and coincides with the shear zone between the Western and the Eastern Dharwar cratons and is quite wide spread that indicates its deep seated nature. The geoid highs, H2 coincide with the SMB and high density rocks north of it and the ADMB in the NW part as described in the next section.

6) Modeling of gravity data across the shear zone (H1) along a seismic section Kavali-Udipi (Profile I, Figure 3), suggested that the gravity high, H1 are caused by high density rocks $\left(2.78 \mathrm{~g} / \mathrm{cm}^{3}\right)$ at shallow depth $(5-6$ $\mathrm{km}$ ) in the upper crust [10] that is also characterized by high velocity [16] and high conductivity [17]. It coincides with the shear zone as thrust extending up to the Closepet granite towards the east. These high density rocks associated with the west verging thrust may represent thrusted lower crustal rocks in this section. It also provided crustal thickening up to $41 \mathrm{~km}$ west of the shear zone from 32 - $34 \mathrm{~km}$ east of it.

7) High density rocks along the shear zone related to 


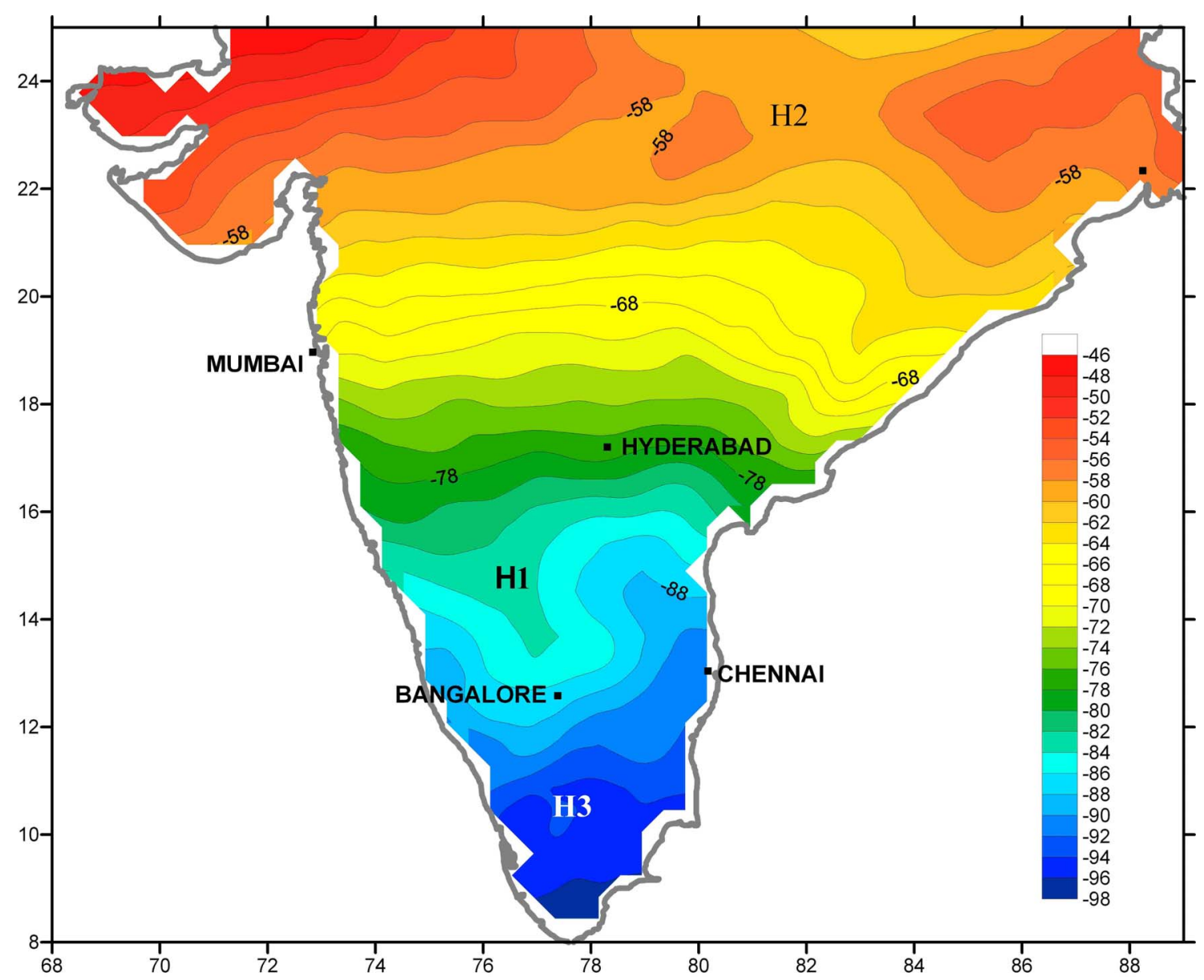

Figure 5. Part of the Indian Ocean geoid low over the Indian Shield in meters showing a regional low and some relative geoid highs, H1-H3. The geoid high, H1 coincides with the shear zone between the WDC and the EDC. The geoid highs, H2 coincide with the SMB and high density rocks north of it and the ADMB in the western part.

the gravity highs, $\mathrm{H} 1$ extend east wards up to the Closepet granite coinciding with a thrust that along with the thin crust $(\sim 32 \mathrm{~km})$ in this section and crustal thickening west of it suggest that the shear zone represents a suture and a thrust. Schist belts of the WDC with bimodal volcanics of Neoarchean time formed in marginal basins due to $\mathrm{E}-\mathrm{W}$ convergence and subduction across the shear zone.

\subsection{Southern Granulite Terrain}

It is defined by gravity anomalies, H2-H5 and L2-L5 (Figures 2 and 3) that are discussed below. The gravity anomalies, H18 and L18 also occur in this section that is dealt in a separate section on the EGMB. Figure 3 also shows Profile II \& III across the eastern and the western part of the SGT and geophysical data along them are described below for plausible collision tectonics.

1) The terrain south of the Eastern and the Western Dharwar cratons separated by the transition zone is known as the SGT (Figure 3). It is largely occupied by lower crustal granulite rocks and several deep seated intrusives of Neoarchean-Paleoproterozoic period [2.55 Ga; 18]. It is also characterized by several shear zones and thrusts such as Moyar Bhavani shear zone (MBSZ) and Palghat Cauvery shear zone (PCSZ; Figure 3). These two major shear zones enclose the linear Cauvery shear zone (CSZ) where rocks of different ages mostly from Paleoproterozoic to Neoarchean periods are reported. This section is also known as Palghat gap as it represents a geomorphological low land that is affected by recent tectonic activity causing rifting [19]. The terrain south of the CSZ is also characterized by Pan African event of Neoproterozoic-Cambrian times [0.55 Ga; 18].

2) The important gravity anomalies in this section are H2 - H5 and L2 - L5 (Figure 2). The gravity highs and lows, H2 and L2 are E-W oriented linear gravity anomalies that are associated with the eastern part of the transition zone (Palar shear) and separates the EDC and the 
SGT of different rock types and therefore significant for collision tectonics. Similarly, the gravity highs and lows, H3, H5 and L3 in the western part are sub parallel to each other and related to the NE-SW oriented MBSZ that separates the WDC and the SGT and is therefore likely to be related to collision tectonics. It is interesting to note that the gravity highs, $\mathrm{H} 2$ in the eastern part extends from transition zone northwards for almost $100 \mathrm{~km}$ indicating that in case this gravity high is attributed to high density thrusted lower crustal/ upper mantle rocks, this part of the transition zone has acted like a thrust. In fact, the transition zone in this section is slightly modified based on the southern gradient of the gravity highs, H2. It is supported from the geological observation that rocks east of the Kolar schist belt (KSB, Figure 3) that coincides with the gravity highs, $\mathrm{H} 2$ is derived from $\mathrm{Mg}$ rich andesites from upper mantle while rocks towards the west of this schist belt is reworked crust [20]. This indicates that the differences in rock types on either side of the Kolar schist belt can be attributed to the effect of thrusting from the SGT on the eastern side while the western side is the reworked crust of the EDC.

3) Multidisciplinary geophysical investigations in the SGT along Profile II [Figure 3; 21,22] suggested crustal thickening of about $45 \mathrm{~km}$ under the SGT that reduces to about $38 \mathrm{~km}$ under the CSZ. Based on the airborne magnetic data Mishra et al. $[19,22]$ suggested that the MBSZ and PCSZ join with the Mettur and Gangavalli shears, respectively towards the east as shown in Figure 3. Modeling of the airborne magnetic and gravity data along Profile II (Figure 3) across the CSZ suggested opposite dipping shear zones on either sides of it and the CSZ is associated with high density, high susceptibility rocks that suggest the CSZ as the central core complex of this collision with mafic/ultramafic rocks in the central part. The gravity highs, H2 Figure 2 coinciding with the eastern part of the transition zone from Banglore to Chennai (Palar shear, Figure 3) is modeled due to high density intrusive in the upper crust that extends north of the transition zone and may represent a $\mathrm{N}$-verging thrust related to this collision with N-S convergence. Simultaneous modeling of airborne magnetic and gravity data from this section for the first time provided the density and susceptibility characteristics of rocks along the transition zone $(\mathrm{H} 2$, Figure 2) that suggest mafic granulite rocks.

4) The gravity highs, $\mathrm{H} 3$ representing the western part of the transition zone-Moyar shear separate the WDC towards the north and the SGT towards the south. It is flanked by two gravity lows L1 towards the north and L3 towards the south separated by the transition zone and the Moyar shear, respectively. A gravity profile $75.5^{\circ} \mathrm{E}$ (Profile III, Figure 3) across the gravity high, H3 and lows, L1 and L3 (Figure 2) is given in Figure 6(a) that shows a gravity high (H3) in the central part associated with exposed lower crustal granulite rocks of Coorg hill and crustal thickening under the WDC (L1) and the SGT (L3) separated by the transition zone and the Moyar shear, respectively. The gravity high, H3 associated with the lower crustal rocks of Coorg hill is modeled due to high density $\left(2.82 \mathrm{~g} / \mathrm{cm}^{3}\right)$ south dipping body that may represent thrusted blocks along the north verging Moyar shear and gravity lows, L1 and L3 are cused by crustal thickening of 52 and $50 \mathrm{~km}$, respectively. A higher density for the lower part of the crust is adopted in the present case as receiver function analysis suggested a mafic crust under the WDC [14]. The linear gravity highs, H5 (Figure 2) extending from the west coast up to south of Banglore related to Bhavani shear zone is almost sub parallel to gravity highs and lows, H3 and L3 related to Moyar shear and appear to form a set of anomalies that defines the MBSZ as suture and thrust in the western part between the WDC and the SGT with N-S convergence and subduction similar to those across the eastern part of the transition zone between the EDC and the SGT.

5) The above convergence and subduction gave rise to thick crust $(\sim 50 \mathrm{~km})$ under the southern part of the WDC and adjoining western part of the SGT that may represent the crustal root where maximum crustal thickness in the entire Indian shield is observed. Based on the thermal, petrologic and geological studies in Slave and Churchill provinces of the Canadian Shield Schmidberger et al. [24] have suggested that roots under Archean provinces were formed at convergent margins which indicate that these sections of the WDC and the SGT are part of convergent margins as described above. It has been even suggested that cratonic roots were formed due to vertical stacking of the subducted plate that soon become strong to resist deformation and thereby control the tectonics of that region.

6) Simultaneous E-W and N-S directed convergence across the shear zone and the transition zone, respectively suggest that primary stress direction might be NESW with these components that would cause oblique convergence across these sutures which has been suggested based on geological signatures in case of the shear zone between the WDC and the EDC [11]. Dominant NW-SE structural lineaments such as Koyna and Kurduwadi lineaments (L6 and L7, Figure 2) in the Indian shield also support NE-SW oriented primary stress direction during Neoarchean-Paleoproterozoic period.

7) Figure 6(b) is a schematic representation of convergence and subduction across the MBSZ and the PCSZ during Neoarchean-Paleoproterozoic period that explains the contemporary granulite rocks in the northern part. It shows the subduction of the Dharwar craton across the MBSZ and Madurai block across the PCSZ that have given rise to high grade rocks of these sections and the 


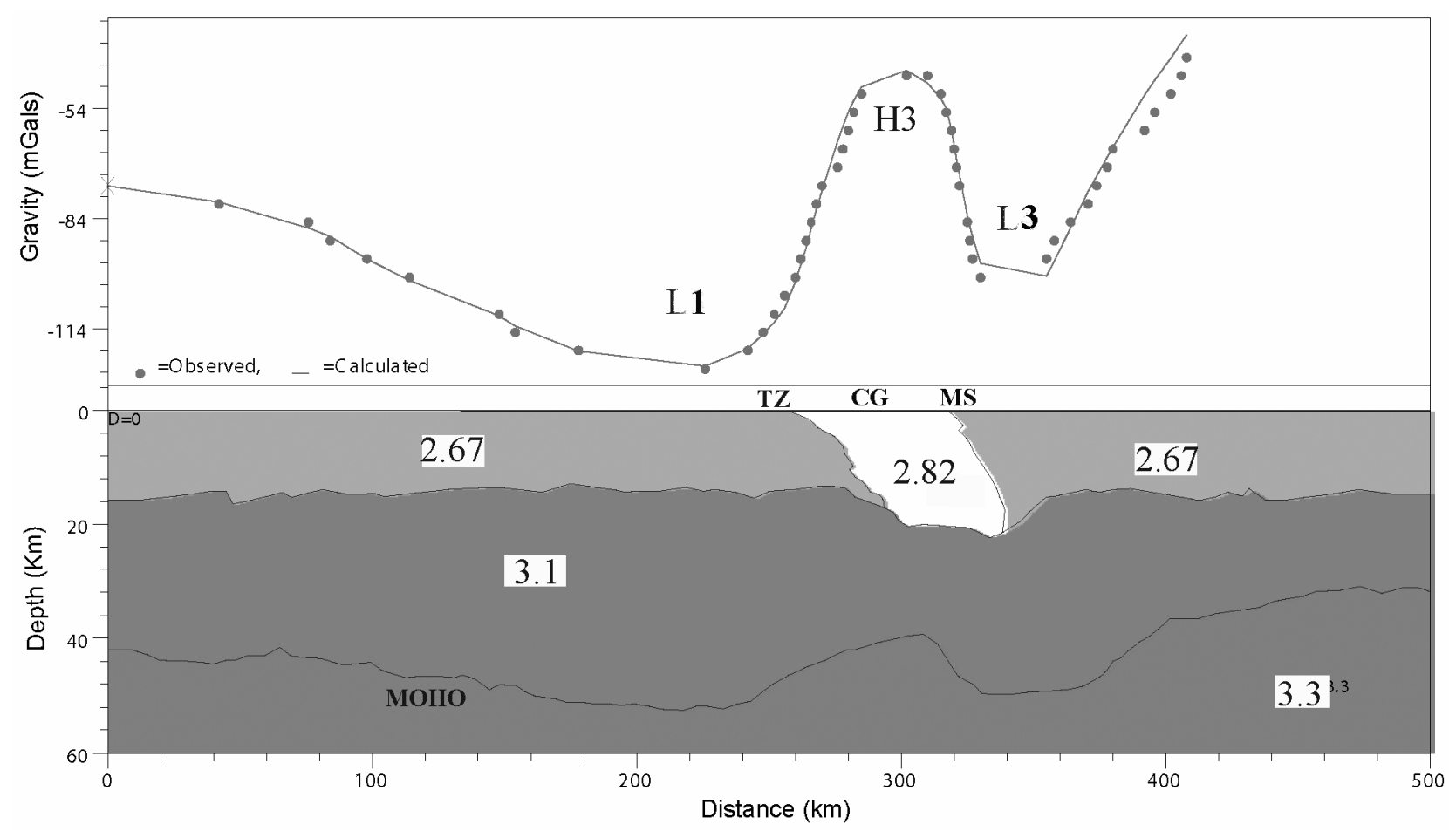

(a)

Central core complex between MBSZ \& PCSZ

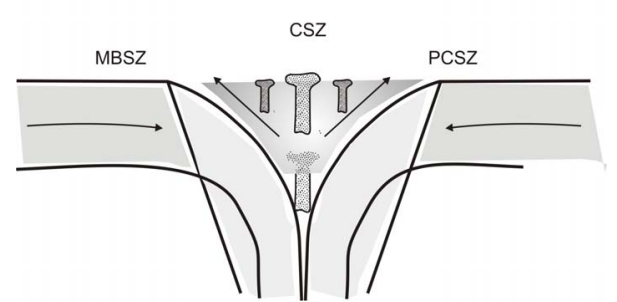

(b)

Figure 6. (a) A gravity profile along $75.5^{\circ} \mathrm{E}$ across the WDC and the SGT (Profile III, Figure 3) with gravity lows, L1 and L3 and intervening gravity high, $\mathrm{H3}$ located along this profile (Figure 2). The computed model shows crustal thickening up to 50 - $52 \mathrm{~km}$ for the gravity lows and thrusted high density $\left(2.82 \mathrm{~g} / \mathrm{cm}^{3}\right)$ lower crustal rocks of Coorg hills (CG) for the gravity high. $\mathbf{T Z}=$ Transition zone and MS = Moyar shear. (b) A schematic cross section of convergence between the Dharwar craton and the Madurai block across the CSZ between the MBSZ and the PCSZ where two cratons have collided to form Central Core Complex of this collision zone where several mafic/ultramafic and other deep seated intrusives are found shown as flowers. Horizontal arrows (N-S and S-N) indicate convergence and subduction while inclined arrows indicate thrusting.

CSZ as central core complex with mafic/ultramafic intrusives of this collision. This is related to NeoarcheanPaleoproterozoic convergence, north of the PCSZ while Neoproterozoic-Cambrian ages, south of the PCSZ have been attributed to a subsequent Pacific type subduction from the north to the south across the PCSZ [25] that have been related to the final amalgamation of Gondwana Supercontinent [26]. This implies repeated cycles of convergence in this section. Raval and Veeraswamay [27] have suggested that the shear zones of the SGT, MBSZ and PCSZ join with those from Dharwar craton, Kurduwadi lineament and Godavari graben to further divide the EDC in two parts.

\section{Central Indian Cratons and Mobile Belts}

This region in central part of India consists of Bundelkhand craton towards the north of the SMB and Bhandara (BC)-Bastar and Singhbhum cratons towards the SE and Dharwar craton towards the SW separated by GodavariProterozoic Belt (GPB) along the Godavari graben (Figure 1). Figure 7 [28] provides detailed geological and tectonics of central and western India related to the SMB and the ADMB that are discussed below in detail. This 
map also shows Profiles I-V across the ADMB and the SMB and geophysical data along them are described below in detail for Proterozoic collision tectonics.

\subsection{Satpura Mobile Belt and Adjoining Cratons}

It is defined by gravity anomalies, H8-H16 and L8-L16 (Figure 2) that are discussed below.

1) The SMB is characterized by rocks of Paleo-Mesoproterozoic period (Figure 7, Table 1). Table 1 summarizes details of some significant geological events of the SMB and adjoining cratons and mobile belts (ADMB) related to convergence and collision tectonics for a comparative study. The central part of the SMB showing high grade granulite rocks and high grade Sausar metasediments of Mesoproterozoic period along the Central Indian Shear (CIS) and Bhandara-Bastar craton south of the SMB showing contemporary island arc type magmatic rocks in back arc basin type set up was suggested to represent a N-S directed collision zone and subduction [30]. In the western part it is joined to the Aravalli Delhi Mobile Belt (ADMB, Figures 7) that has also been considered as an E-W directed Proterozoic collision zone between the Bundelkhand craton towards the east and Rajasthan block towards the west based on geological signatures [31] which gave rise to Aravalli and Delhi orogenies (Table 1). The section west of the ADMB is occupied by the Erinpura granite and the Malani Rhyolites of Neoproterozoic time (8.0 - 7.5 Ga, Table 1) that represent subduction related magmatism of that time.

2) The SMB shows linear gravity highs, H8-H9 and lows, L8-L9 south of it (Figure 2) that formed paired gravity anomalies requiring detail examination for collision tectonics. Modeling of gravity anomalies along Profile II \& III (Figure 7) suggested a high density body at a depth of 8 - $10 \mathrm{~km}$ for the central gravity highs related to the SMB [13,31] coinciding with a high conductive body (Sarma et al., 1996) that suggested lower crustal rocks at

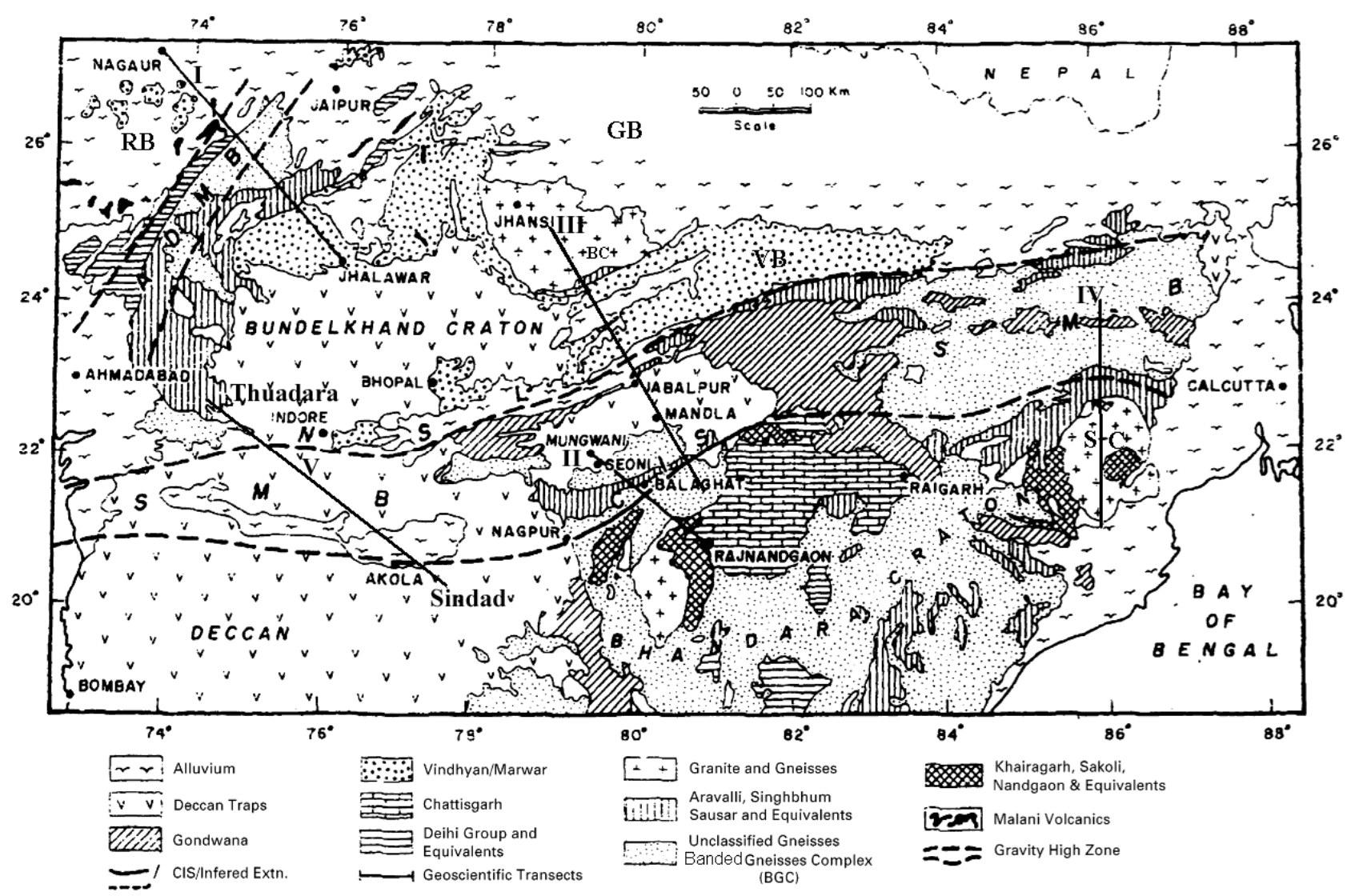

Figure 7. Geological map of the North Indian Shield that includes the Satpura Mobile Belt (SMB), the Aravalli-Delhi Mobile Belt (ADMB), and the adjoining cratons (GSI, 1993). The Central Indian Shear (CIS) is shown in the central part of the southern margin of the SMB whose northern margin is the Narmada-Son lineament (NSL). The geotransects 'Nagaur-Jhalawar' (I) and 'Mungwani-Rajnandgaon' (II) across the ADMB and the SMB and zones of gravity 'highs' along them are also shown. Three other profiles III-V across the SMB have been investigated and compared with the results along the geotransects (I-II). BC—Bundelkhand craton, GB-Ganga Basin, RB-rajasthan Block, SC—Singhbhum craton, VBVindhyan basin. 
Table 1. Some important tectonic events and intrusive of the ADMB and the SMB and adjoining cratons (Figure 1).

\begin{tabular}{|c|c|c|c|}
\hline Age & ADMB [31 and references there in] & $\begin{array}{l}\text { SMB: Central Part of SMB and Bastar } \\
\text { Craton [30,70 and references there in] }\end{array}$ & $\begin{array}{l}\text { SMB: Eastern Part and Singhbhum } \\
\text { Craton [58 and references there in] }\end{array}$ \\
\hline Neo-Proerozoic & $\begin{array}{l}\text { Post Delhi magmatism: Einpura grnite } \\
\text { and Malani volcanics: } 0.8 \text { - } 0.7 \mathrm{Ga} \\
\text { Back arc basins } \\
\text { with bimodal volcanics: } 0.9 \text { - } 0.8 \mathrm{Ga}\end{array}$ & & \\
\hline Meso-Proterozoic & $\begin{array}{c}\text { End of Delhi orogeny: } 1.0 \mathrm{Ga} \\
\text { Deformation and thrusting } \\
\text { of Delhi rocks: } 1.1 \mathrm{Ga} \\
\text { Delhi rifting and Delhi supergroup } \\
\text { of rocks: } 1.5 \mathrm{Ga}\end{array}$ & $\begin{array}{l}\text { End of Sausar orogeny: } 1.0 \mathrm{Ga} \\
\text { Southern granulite rocks: } 1.0 \mathrm{Ga} \\
\text { Mangikota volcanics: } 1.0 \mathrm{Ga} \\
\text { Kairagarh volcanics: } 1.4 \mathrm{Ga} \\
\text { Sausar meta sediments } \\
\text { and gneisses/migmatite complex } 1.5 \mathrm{Ga}\end{array}$ & $\begin{array}{l}\text { End of Singhbhum orogeny: } 0.9 \text { - } 1.0 \mathrm{Ga} \\
\text { Southern granulite belt in CGGC } \\
\text { Gangpur granite intrusive } 1.0 \mathrm{Ga} \\
\text { Mayurbhanj granite } 1.2 \mathrm{Ga} \\
\text { Chankradarpur granite-gneiss } 1.5 \text { - } 1.1 \mathrm{Ga} \\
\text { Anorthosite gabbro } 1.5 \mathrm{Ga}\end{array}$ \\
\hline Paleo-Proterozoic & $\begin{array}{c}\text { End of Aravalli orogeny: } 1.6 \mathrm{Ga} \\
\text { Granite of north Delhi fold belt } \\
\text { and base metal mineralization: } 1.7-1.6 \mathrm{Ga} \\
\text { Darwal and Amet granite: } 1.9-1.7 \mathrm{Ga} \\
\text { Sandmata lower crustal granulite rocks, } \\
\sim 1.9 \mathrm{Ga} \\
\text { Aravalli rifting and supergroup of rocks: } \\
\sim 1.9 \mathrm{Ga} \\
\text { Berach granite: } 2.5 \mathrm{Ga}\end{array}$ & $\begin{array}{c}\text { End of Mahakoshal orogeny: } 1.6 \mathrm{Ga} \\
\text { Dormation of Mahakoshal rocks } \\
\text { and northern granulite rocks: } 1.6 \mathrm{Ga} \\
\text { Mahakoshal group of rocks: } 2.0 \mathrm{Ga} \\
\text { Sakoli and Nandagon bimodal volcanics } \\
\text { of back arc type: } 2.2 \mathrm{Ga} \\
\text { Dongargarh and Malanjkh and K-granite, } \\
\text { Island ar type: } 2.3 \mathrm{Ga} \\
\text { Granite intrusions: } 2.4 \text { - } 1.6 \mathrm{Ga}\end{array}$ & $\begin{array}{l}\text { Ultramafic intrusions northern granulite belt } \\
\text { in CGGC } 1.6 \text { - } 1.5 \mathrm{Ga} \\
\text { Kohan group 1.6 - } 1.5 \mathrm{Ga} \\
\text { Dalma-Chandeli-Dhanjori volcanics. } 1.7 \mathrm{Ga} \\
\text { Dhaibhum stage } \\
\text { Chaibasa stage }\end{array}$ \\
\hline Archean & $\begin{array}{l}\text { Untala and Gingla granite: } 2.9 \mathrm{Ga} \\
\text { Banded gneissic complex: } 3.5 \mathrm{Ga}\end{array}$ & $\begin{array}{l}\text { Unclassified granite and gneisses } \\
\text { (Amgaon, Sukma etc.): } 3.0 \text { - } 3.5 \mathrm{Ga}\end{array}$ & $\begin{array}{l}\text { Singhbhum granite (2.95 Ga) } \\
\text { Older metamorphic group (3.3 Ga) }\end{array}$ \\
\hline
\end{tabular}

shallow depth in this section and crustal thickening southwards under the Bhandara craton. Gravity modeling also suggested that the Central Indian Shear (CIS) as a north verging thrust that also depicted dipping reflectors from two sides [33] and high conductivity indicating a suture and a thrust. The low density and low velocity rocks were inferred below the Moho south of the SMB under Bhandara craton that was attributed to remanent of subducting rocks in this section [31]. A high reflective lower crust in seismic profiles across the SMB also indicate an extensional phase that may be related to the activity prior to this compressional phase as envisaged in 5) when Mahakoschal-Bijawar group of rocks were deposited.

3) North verging thrusts, along the CIS and Sausar orogeny with granulite rocks of Meso-proterozoic period along the CIS and contemporary island arc type magmatism in back arc type settings of Bhandara-Bastar craton (Table 1) suggest collision of Bundelkhand and Bhandara-Bastar cratons in the central part of the SMB with convergence and subduction from the north to the south during this period with the CIS representing a Mesoproterozoic suture.

4) The gravity highs, $\mathrm{H} 8$ of the central part of the SMB extends to the eastern part of the SMB comprising Chhota Nagpur Granite Gneiss Complex (CGGC) as gravity highs, $\mathrm{H} 15$ and $\mathrm{H} 16$ related to the northern and the southern belts of high density granulite rocks (Table 1). This table provides a good correspondence in the rock types occurring in the CGGC and Singbhum craton south of it with those from the central part of the SMB and
Bastar craton south of it. Based on the rock types of the Singhbhum craton being similar to the island arc type, Banerjee (1982) had suggested collision and subduction during Mesoproterozoic period from the north to the south in this part of the SMB that was also supported from geophysical data from this section indicating the extension of Satpura orogeny towards the east [34].

5) The gravity highs, H12 and H13 (Figure 2) encircling the Bundelkhand craton partially coincide with the exposed Bijawar group of rocks (Figure 7) consisting of metasediments and mafic/ultramafic intrusive of Paleoproterozoic period $(\sim 1.9 \mathrm{Ga})$ and that along with the contemporary Mahakoshal Group of rocks (H15) with dominant mafic and ultra mafic components at southern end of the Vindhyan basin suggest that these rocks deposited in rift basins on rifted platform of the Bundelkhand craton [35]. These group of rocks presently occupy horst as seen in seismic section [36] that were uplifted and disturbed during the Mesoproterozoic convergence as described above. Subsequently, the Lower Vindhyan group of rocks [Semri Series, $1.7 \mathrm{Ga}$; 37] was deposited on the rifted platform with Paleoproterozoic group of rocks as basement and the Upper Vindhyan group of rocks [1.1 - 0.7 Ga, 38] was deposited during Meso-NeoProterozoic convergence along the SMB in a foreland basin that explains a long hiatus between the Lower and the Upper Vindhyan Groups [39,40].

6) Based on low-medium grade supracrustal belts, gneisses, granitoids and granulite belts with several crustal scales shear zones and tectonothermal events; Roy and Prasad [41] suggested continent-continent colli- 
sion at $\sim 1.5 \mathrm{Ga}$ and $\mathrm{S}-\mathrm{N}$ subduction in this section. In fact all these features are typical characteristics of mobile belts world over. Naganjaneyulu and Santosh [42] based on directions of reflectors in seismic profiles, suggested both ways subduction, viz. S-N and N-S. They have also attributed high conductive body in the upper crust to Deccan trap activity though such bodies are characteristics of mobile belts world over and are attributed to upper mantle/lower crustal rocks thrusted during orogeny and presence of fluids with them [31]. However, to understand the direction of convergence and subduction, data from the adjoining terrane of basins and cratons play an important role. In present case, Mahakoshal and Vindhyan groups of rocks towards the north of the SMB represent typical rifted platform and foreland basin deposits, respectively (Section 7.6.2). Similarly, the Bhandara craton towards the south with larger crustal thickness and contemporary rift basins with bimodal volcanics perpendicular to the SMB suggest that subduction was from N-S across the SMB. However, some limited subduction also from the south to the north can not be ruled out as two ways subduction is quite common during continent- continent collision.

7) Older granites of Paleoproterozoic period of Bhandara and Singhbhum cratons such as Dongargarh and Malanjkhand granite and Singhbhum granite plutons and Sakoli and Nandgaon volcanics (Table 1) suggest that there might have been a convergence also during Neoarchean-Paleoproterozoic period in this section. Margin of the Malanjkhand granite $(\sim 2.5 \mathrm{Ga})$ close to the CIS is mylonitized [43] that also indicate a convergence during this period.

8) The western part of the SMB is covered by Deccan trap and there are no exposures of Archean-Proterozoic rocks in this section to examine for plausible collision tectonics of that time. Geophysical data has been found to be useful in such situations. A gravity profile V (Figure 7) from Thuadara-Sindad across the western part of the SMB is modeled constrained from the seismic profile [44] to check on the sub surface structures related to collision tectonics in this part of the SMB. This gravity profile (Figure 8(a)) shows a high over the SMB (H8, Figure 2) and low (L8) south of it that are modeled due to a high density body in the upper crust under the SMB separated by Tapti lineament. This crustal structure is almost similar to that described above along profile II \& III (Figure 7) with Tapti lineament representing the suture as the CIS in the central part of the SMB. Conductivity distribution [45] along the same profile also provided blocks of different conductivity on either side of the Tapti lineament with high conductivity in the upper crust under the SMB similar to those along profile II (Figure 7) across central part of the SMB. These obser- vations indicate that the western part of the SMB also represents a Proterozoic collision zone similar to its central part as discussed above signifying that the entire SMB was involved in Proterozoic collision.

9) Another important data set related to Proteozoic collision and subduction across the western part of the SMB is the conductivity distribution south of it under the Deccan Volcanic Province (Figure 7) along a profile from Partur to Sangole (Figure 1). This conductivity profile [Figure 8(b), 46] shows an upper mantle conductor that dips consistently south wards almost at $45^{\circ}$ reaching to shallow depth of $8-10 \mathrm{~km}$ in the upper crust near Partur, close to the SMB. High conductive body almost at same depth of $8-10 \mathrm{~km}$ has been delineated under the SMB along profiles II and V as reported above. A gravity profile from the western part of the SMB, north of Partur to south of Sangole adopted from Figure $\mathbf{2}$ is also given in Figure 8(b) that shows a regional gravity gradient increasing consistently towards the SMB in the same manner as the upper mantle conductor indicating an interface separating rocks of different densities. These two characteristics of high conductivity and high density for the upper mantle conductor suggest that it may represent rocks with fluids such as serpentine indicating a paleo-subduction and suture zone during the Proterozoic collision along this part of the SMB that also confirms N-S convergence in this section.

\subsection{The Aravalli Delhi Mobile Belt and Its Interaction with the SMB}

1) Gravity highs, H14 (Figure 3) is part of the gravity highs due to the ADMB that extend from SW to NE up to Himalaya [31]. The geological details of the ADMB is shown in Figure 7 and summarized in Table 1. The geophysical anomalies and crustal model across the ADMB [31] suggest an E-W convergence during Meso-Neoproterozoic period with east verging Delhi thrust and exposed ophiolite rocks along the western margin as a suture which gave rise to Delhi orogeny and contemporary magmatic rocks, Erinpura granite and Malani volcanics ( 800 Ma) west of it [31]. Back arc basins with bimodal volcanics [47] and hydro thermally altered basaltic rocks [ 760 Ma, 48] west of the ADMB further confirm E-W convergence during this period. Aravalli orogeny and various felsic intrusives of Paleoproterozoic period (Table 1) also suggest a convergence phase during this period with the Jahazpur thrust coinciding with the Great Boundary fault at the surface (Figure 7) as a suture. It was followed by a rifting phase during PaleoMesoproterozoic period as in case of the SMB described above that gave rise to Aravalli Group of Rocks in the ADMB [31; Table 1]. This rifting phase also gave rise to 

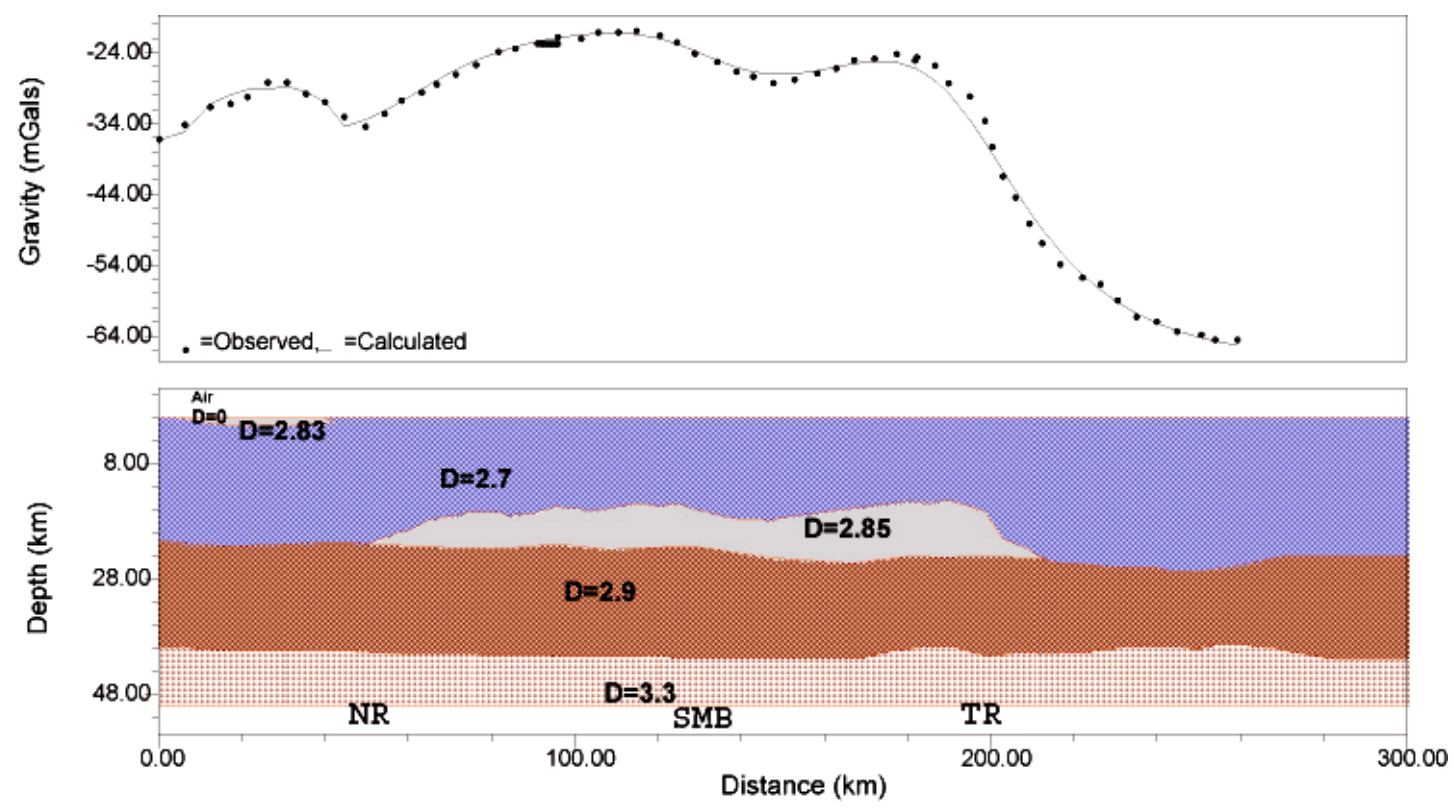

(a)

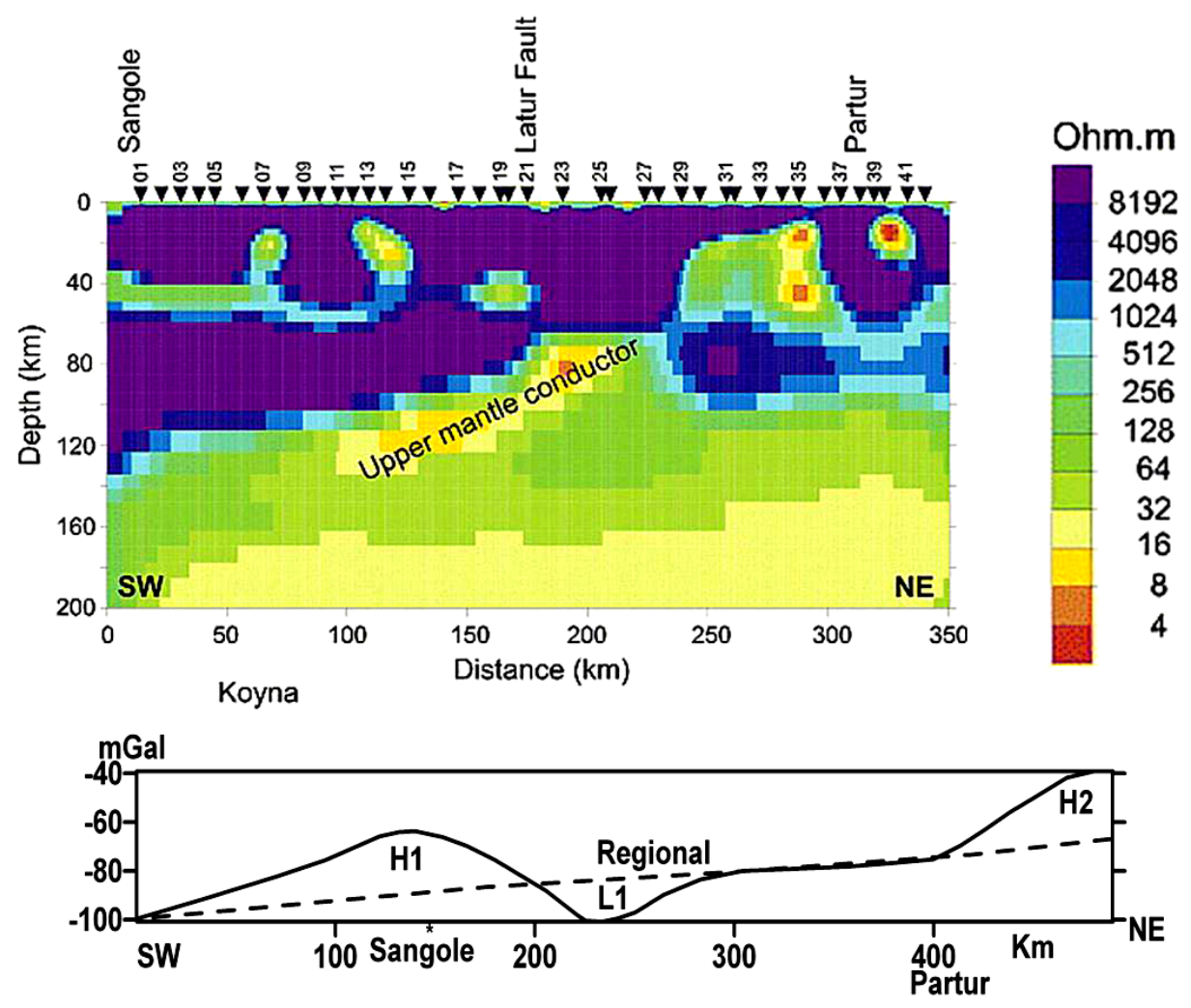

(b)

Figure 8. (a) Gravity profile across the western part of the SMB from Thuadara to Sindad (V, Figure 7) showing gravity high over the SMB due to high density intrusive in the upper crust and low south of it separated by Tapti River (TR; lineament). NR-Narmada River. (b) Two dimensional geoelectric model based on MT profile Sangola-Partur (Figure 1, Patro and Sarma, 2009) showing an upper mantle conductor in lithospheric mantle with decreasing depth north wards towards the Proterozoic Satpura Mobile Belt. The second profile below is the Bouguer anomaly from SW of Sangole to NE of Partur that shows a regional gravity high increasing up to the western part of the SMB. Gravity highs, $\mathrm{H} 1$ and $\mathrm{H} 2$ are residual gravity highs, the latter (H2) being related to the SMB. 
rocks contemporary to Bijawar and Mahakoshal Group of Rocks along the ADMB east of the Great Boundary Fault that formed the basement of the Vindhyan basin in this section over the rifted margins of the Bundelkhand craton [35].

2) The gravity highs due to the SMB, H8 and H9 and ADMB, H14 form curvilinear mobile belt between the Bundelkhand craton in the central part and Rajasthan block towards the west and Dharwar-Bhandara-Singhbhum cratons towards the south (Figures 1 and 7) with E$\mathrm{W}$ convergence across the ADMB and N-S convergence across the SMB during Paleo-Mesoproterozoic periods with a rifting phase in between.

3) Contemporary N-S convergence of Bundelkhand craton across the SMB and its E-W convergence across the ADMB suggest primary stress direction as NE-SW with E-W and N-S components. It is supported by NWSE oriented large lineaments and shear zones in the Bundelkhand and the Dharwar cratons.

\subsection{Godavari Proterozoic Belt (GPB) and Proterozoic Triple Junction}

It is defined by the gravity anomalies, $\mathrm{H} 10-\mathrm{H} 11$ and L10-L11 (Figures 1 and 2) that are discussed below.

1) This section is characterized by Gondwana (Permian-Triassic) sediments in the central part [49] flanked by Paleo-Neoproterozoic metasediments of Pakhal-Sullavai basins [50] that are exposed on either sides of the Godavari Gondwana graben (Figure 1). Figure 2 shows a central gravity low, L10 related to Gondwana sediments flanked by gravity highs, H10 and H11 that coincides with the Paleo and Neoproterozoic metasediments of the Pakhal and Sullivai Group of Rocks along the shoulders. North of the exposed Proterozoic rocks is the Bhandara-Bastar craton that consists of several basins of Paleo-Mesoproterozoic period. The contact of BhandaraBastar craton with the Proterozoic metasediments of Godavari Proterozoic Basin consists of Bhopalpatnam granulite belt of $1.6 \mathrm{Ga}$. The southern part of the Godavari Proterozoic basin is in contact with the Dharwar craton that is characterized by Karimnagar granulite belt of $2.4-2.2 \mathrm{Ga}$ at its contact [51]. However, the latter (southern part) also shows a thermal event of 1.6 Ga that has been reported from Karimnagar dykes in the vicinity of the granulite belt [52] which is contemporary to Bhopalpatnam granulite belt.

2) A gravity profile (Figure 9(a)) across Chintalpudi sub basin in the southern part of the Godavari basin (H10, H11 and L10, Figure 2) is modeled constrained from seismic section [53] limited to the central part of the profile (L10) that shows a high density layer in the upper crust (5 - $6 \mathrm{~km}$ ) in the central part popping up along the shoulders supported from high seismic velocity in the central part. This may represent the thrusted lower crustal rocks that are exposed in some parts as Karimnagar and Bhopalpatnam granulite belt described above.

3) Airborne magnetic anomaly of large amplitude ( $\sim 50 \mathrm{nT}$, Figure 9(b)) at a height of about 9000' ( 2.7 $\mathrm{km}$ a.m.s.l) along southern margin of the Proterozoic Pakhal group of rocks suggest mafic intrusive of high susceptibility $3.0 \times 10^{-3}$ emu at a depth of about $5.3 \mathrm{~km}$ below m.s.l that is almost at same depth where high density and high velocity rocks have been reported above and may represent thrusted mafic intrusive in the basement. The remanant magnetization of this body, Inclination $=-40^{\circ}$ and declination $=300^{\circ}$ required to match the observed and the computed field is typical of PaleoMesoproterozoic rocks [Vindhyan sediments, 54] in this region indicating the period of collision and thrusting. It is also similar to those reported for dykes of the same period in this region [52].

4) Gravity highs over Proterozoic terrain caused by high density bodies in the upper crust and exposed granulite lower crustal rocks (Bhopalpatnam granulite belt) and gravity lows over Archean craton (L11, Figure 2) suggest collision tectonics of Mesoproterozoic period between Bhandara-Bastar and Dharwar cratons that gave rise to this mobile belt with Bhopalpatnam granulite belt of this period and Sullavai metasediments of MesoNeoproterozoic period along the GPB as related foreland basin. This convergence was approximately NE-SW direction, perpendicular to the strike of the GPB that might be related to convergence along the SMB towards north of it as discussed above. Prior to it, there might be another phase of convergence and rifting during Paleoproterozoic period similar to that along the SMB that gave rise to Karimnagar granulite belt of $2.2-2.4 \mathrm{Ga}$. Large scale mafic/ultramafic intrusive associated with the Pakhal Group of rocks delineated from the airborne magnetic anomaly as described above were responsible for rifting prior to Mesoproterozoic convergence when Pakhal Group of rocks was deposited on the rifted platform of the adjoining cratons.

5) The two branches of the SMB viz the Western and the Central parts and the GPB (H8, H9 and H10 and H11, Figure 2) separating Bundelkhand craton towards the north and Bhandara-Bastar craton towards the SE and Dharwar craton towards the SW form a triple junction of Meso-Neoproterozoic period around Nagpur.

\section{Eastern Ghat Mobile Belt and Cuddapah Basin}

They are defined by the gravity anomalies, H16-H20 and L16-L20 (Figures 1 and 2) that are discussed below 


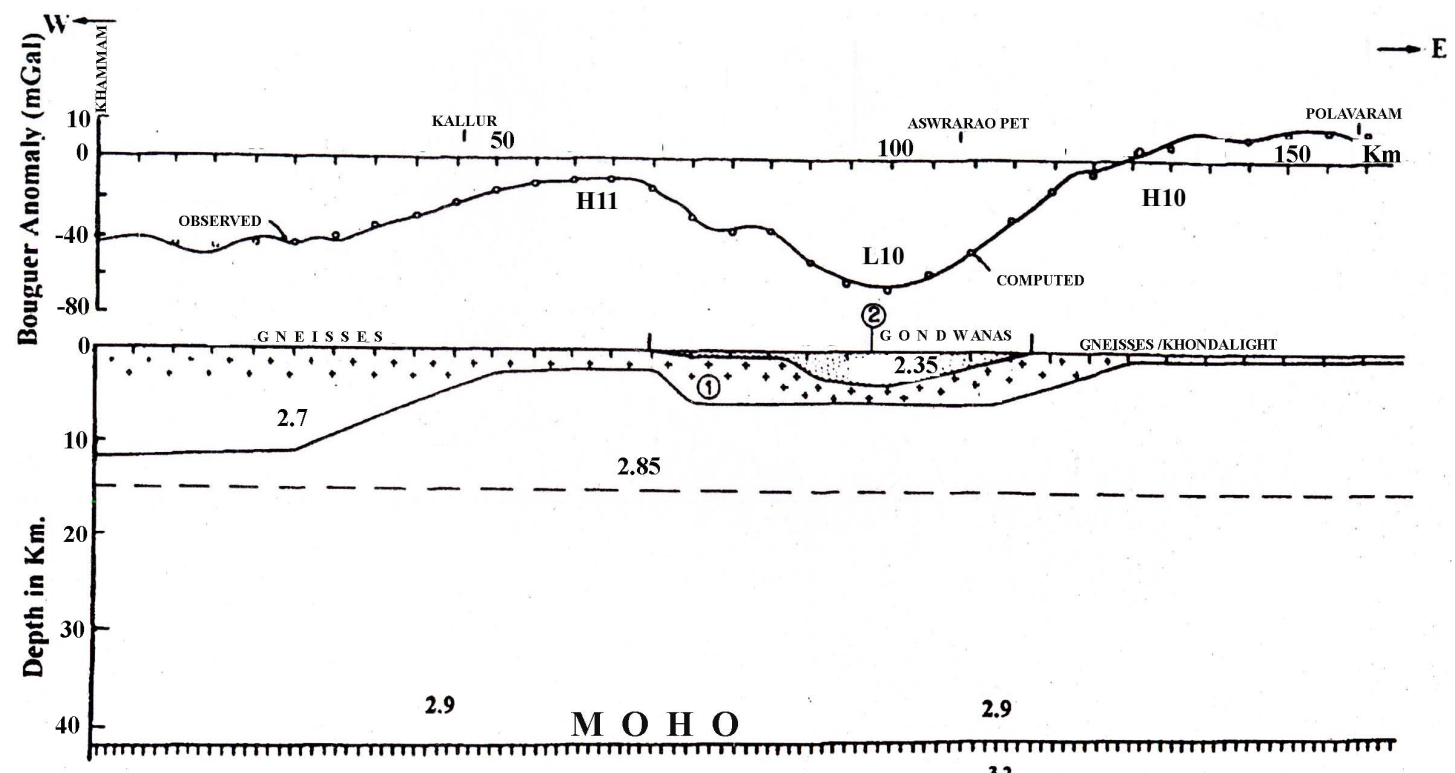

3.2

(a)
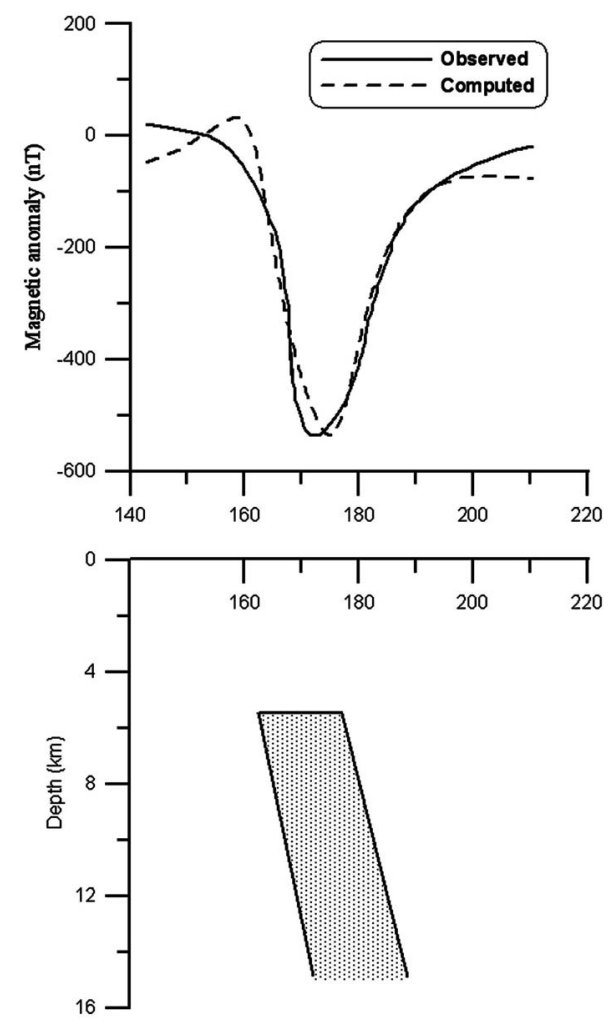

(b)

Figure 9. (a) An E-W gravity profile across the Chintalpudi sub basin and adjoining sections (H10 \& H11 \& L10, Figure 2). The crustal model and its computed field for comparison with the observed field are also shown. It shows high density (2.85 $\mathrm{g} / \mathrm{cm}^{3}$ ) layer at a shallow depth $(5-6 \mathrm{~km})$ in the central part that props up along the shoulders related to highs. Thickness of Gondwana sediments in this sub basin is $3-3.5$ km. Moho is constrained from seismic section. (b) Airborne magnetic anomaly flown at $2.7 \mathrm{~km}$ a.m.s.l over southern part of Proterozoic Godavari basin along Hydeabad -Puri Profile observed over the Pakhal super group of rocks exposed along the SW margin of this basin and modeled source as an intrusive suggesting a depth of $5.3 \mathrm{~km}$ below surface for a susceptibility of $3.0 \times 10^{-3} \mathrm{emu}$ and remanance magnetisation: inclination $=-40^{\circ}$, declination $=300^{\circ}$. 
1) High grade charnockite and khondalite rocks of the EGMB and intrusives have provided wide range of dates from 1.6 - $1.0 \mathrm{Ga}$ [55] that are exposed from south of Bhubaneshwar to north of Chennai (Nellore). However, the most prominent metamorphic event in the EGMB is reported at $1.0-1.1 \mathrm{Ga}$ [56]. The northern part of the EGMB consists of gneisses and migmatites with high grade granulite rocks of Meso-proterozoic period (1.6 $1.5 \mathrm{Ga}$ [ [57], which are similar to those reported from the CGGC [58]. In fact, Dobmeier et al. [59] have provided dates of about $1.6 \mathrm{Ga}$ of magma emplacement and low grade metamorphic overprint of 0.5 Ga related to Pan African event in the EGMB. Vijaya Kumar and Leelanandam [60] have identified two stages of rifting and convergence in southern part of the EGMB, east of the Cuddapah basin during Paleoproterozoic period (2.0 - 1.6 $\mathrm{Ga}$ ) and Mesoproterozoic period (1.55 Ga) to Grenvillian/Pan African collision (1.0/0.5 Ga). The metasediments of Cuddapah basin (Figure 1) abetting the EGMB in the southern part primarily consists of Cuddapah spergroup of rocks of Paleoproterozoic Period [ 1.9 - 1.6 Ga, 61 in the eastern and the western parts of the basin (Horizontal lines, Figure 3) and Kurnool supergroup of rocks of Neoproterozoic period in the central part (broken lines, Figure 3) that is considered mostly undisturbed and free from any volcanic activity. The eastern part of the basin, known as Nallamalai sub basin along the EGMB is highly disturbed with several foldings and faultings and consists of metasediments with several acidic intrusives and lamprophyre dykes that are considered younger than the rocks belonging to the same supergroup of rocks in the western part. The western margin of Cuddapah basin is characterized by large mafic sills in Cuddapah supergroup of rocks that have been dated as $1885.4 \pm 3.1$. Ma [62] indicating that sediments might be even older than this. They have also reported similar dates for some dykes from southern part of the Bastar craton along the northern part of the EGMB (Figure 1) suggesting the existence of a large igneous province at that time in this section. Cuddapah basin is also characterized by occurrences of several minerals such as base metals, barytes etc. including uranium mineralization along the western margin of the basin.

2) The EGMB is largely characterized by gravity highs along the east coast of India (H19-H21, Figure 3) which extends from south of Bhubaneshwar up to Chennai. These gravity highs are caused by high density rocks of $2.8-3.0 \mathrm{~g} / \mathrm{cm}^{3}$ (Figure 10(b)). It is interesting to observe that these highs, H19-H21 are accompanied by gravity low L19-L21 towards the west forming paired gravity anomalies that are significant for Proterozoic collision zone. The linear gravity highs, H19-H21 extend southwards up to southern end along the east coast of
India (H18) and northwards up to Himalaya (H22) along eastern margin of the CGGC where it interacts with the SMB (H15 and H16).

3) The gravity highs and lows, H17 and L17 west of the EGMB (Figure 2) in the southern part are related to the Cuddapah basin (Figure 3) occupied by metasediments and mafic intrusives of Mesoproterozoic period. The gravity high, H17 is located where large mafic flows and sills are exposed while the gravity lows surrounding it coincide with felsic intrusives. The air borne total intensity map of the western part of Cuddapah basin recorded at a terrain clearance of about 500' ( 152 m) with a profile spacing of $1 \mathrm{~km}[63,64]$ provided a complex picture of magnetic anomalies due to several mafic intrusives in the western part of Cuddapah basin as dykes and sills and metamorphosed sediments. The magnetic data west of Cuddapah basin was further complicated due to exposed gneisses and various intrusives that included both mafic dykes and granite batholiths. This data set was reprocessed by correcting for the earth's geomagnetic reference field (IGRF) and filtered for the high frequency components due to surface/shallow bodies that provided a total intensity magnetic anomaly map of the western part of the Cuddapah basin (Figure 10(a)). This map broadly shows a magnetic low (L1) along the S-W margin of the Cuddapah basin with a magnetic high towards north (H1) and south (H2) of it. The amplitude and extent of these magnetic anomalies suggest a large igneous province under the sediments that has given rise to this set of magnetic anomalies, which might be responsible for evolution of this basin. Size of the magnetic anomaly indicates that it may represent a large mafic intrusive in the basement of the western part of this ba$\sin$.

4) The airborne magnetic and gravity data along the eastern part of the deep seismic sounding profile I (Kavali-Udipi, Figure 3) across Cuddapah basin (Figure 10(b)) are simultaneously modeled constraining it from the seismic section [16]. This profile shows gravity highs, H1 and H2 (H17 and H19, Figure 2) related to the western part of the cuddapah basin and the EGMB and intervening low, L1 (L19, Figure 3). The computed crustal model suggests a thrust $\mathrm{T} 1$ of high density under the EGMB and crustal thickening along with under plating (3.05 g/cc) under the eastern part of the Cuddapah basin, west of the EGMB. Thrusting due to this convergence is also supported from high conductivity in the crust reported from the eastern part of the basin [65]. It also suggests a large mafic intrusive (MI) in the basement of high susceptibility (0.002 emu) and remnant magnetization of inclination $6^{\circ}$ and declination $=119^{\circ}$ that is similar to direction of magnetization of sills of Paleo-Mesoproterozoic period exposed in this region [66]. This is an 


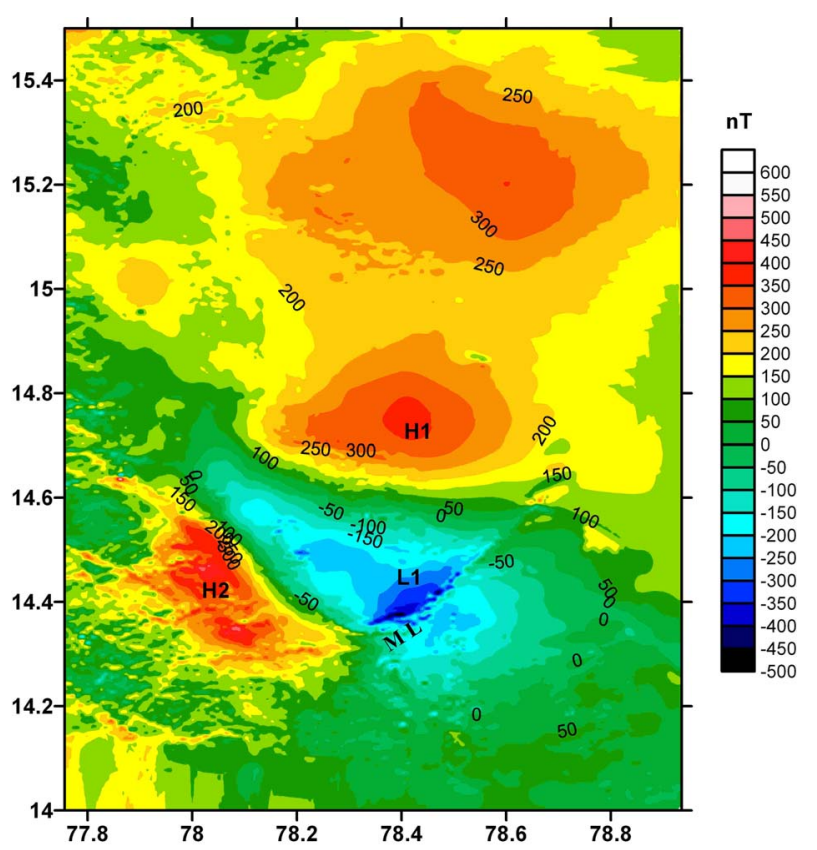

(a)
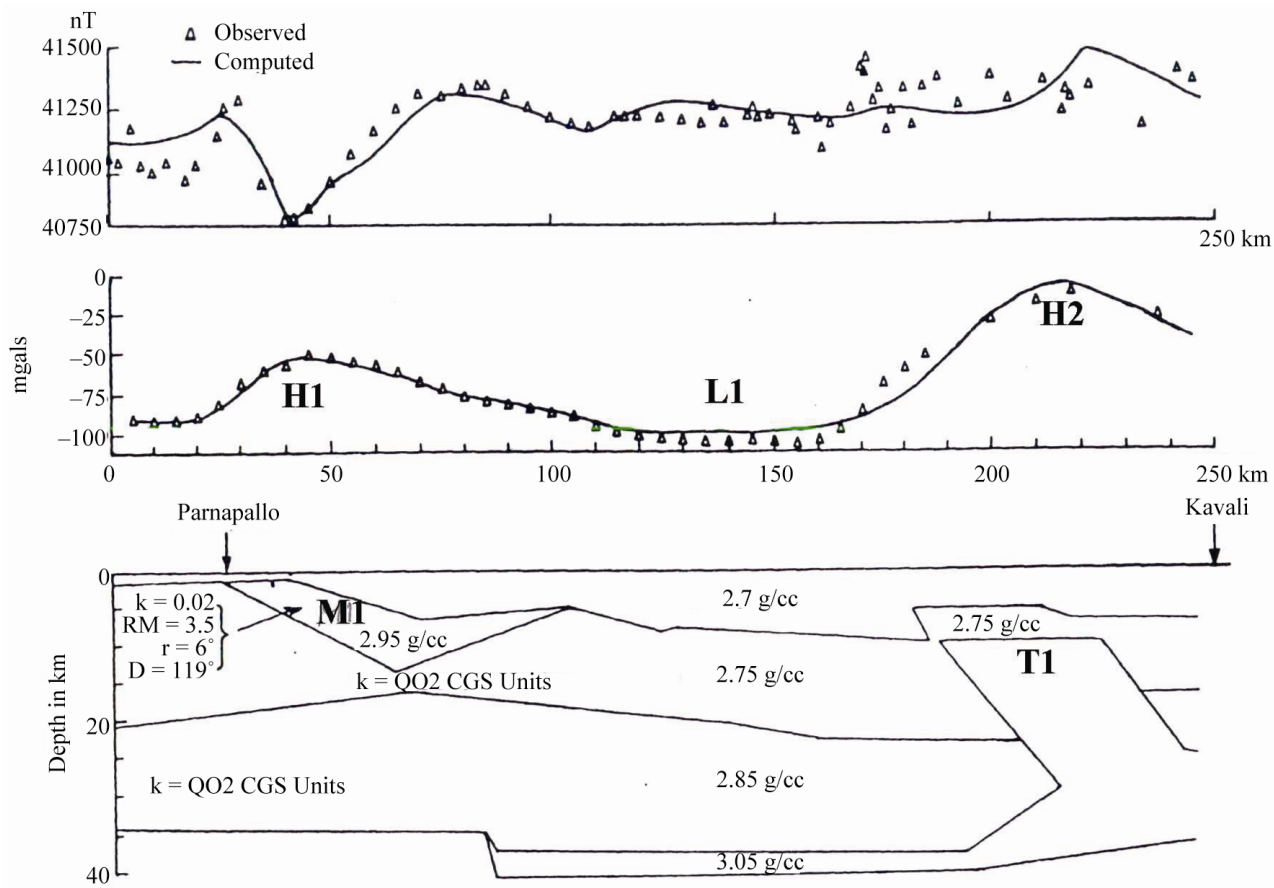

(b)

Figure 10. (a) Airborne total intensity magnetic anomaly map of S-W part of Cuddapah basin flown at 500' ( 150 m) with flight line spacing of $1 \mathrm{~km}$. The IGRF field is subtracted from the observed field. It shows a magnetic high (H1) in the northern part and a low (L1) in the southern part along the S-W margins of the Cuddapah basin. Another high (H2) is observed just outside the SW margin of the Cuddapah basin that coincides with Peninsular gneisses and felsic intrusives. A NE-SW magnetic lineament, ML extends from the Indian shield out side the basin to the southern part of the basin. (b) Bouguer anomaly and airborne total intensity along eastern part of profile I across the EGMB and the Cuddapah basin (Figure 3). The modeled crustal section and the computed fields are also shown with their physical properties mentioned separately for each body. $K$ is susceptibility in c.g.s. units. R.M. is remanent magnetization in $A / m$ and $I$ and $D$ represent the inclination and declination of remanent magnetization. Density is shown in g/cc. MI is mafic intrusive in the basement similar to a lopolith that was responsible for the formation of the western part of the basin. 
asymmetrical mafic lopolith with its thickest part being along the western margin of the basin that might have acted as a conduit. Large mafic body in the western part $(\sim 100 \times 100 \mathrm{sq} \cdot \mathrm{km})$ along with large mafic sills and flows and under plated crust indicates a large igneous province that may represent plume related magmatism. This province has been extending even to the Bastar craton, north of the EGMB (Figure 2) as suggested by French et al. [62]. Simultaneous modeling of the gravity and magnetic fields across the Cuddapah basin for the first time defined the large mafic intrusive (MI, Figure 10(b)) as the basement and underplated crust that are typically found under volcanic provinces.

5) West verging thrust under the EGMB with predominant Mesoproterozoic ages (1.5 - 1.0 Ga) formed due to collision of the Indian continent and East Antarctica along with crustal thickening west of the EGMB as suggested above from gravity modeling and seismic studies suggest east to west convergence during this period that is also supported from contemporary direction of convergence in North Indian Shield across the ADMB (Figure 1). This is related to Grenvillian agglomeration where eastern margin of India was juxtaposed with the East Antarctic shield indicating the collision of the two. This convergence also might be NE-SW similar to the previous cases as suggested by similar oriented (NE-SW) shear zones with large strike slip displacement due to shearing stress [67].

7) Large scale mafic intrusive of Cuddapah basin that is spread over a wide area indicate contemporary plume activity at $\sim 1.9 \mathrm{Ga}$ that was responsible for rifting of cratons in this section. The contemporary Cuddapah Supergroup of rocks (Nallamalai subbasin) was deposited during this rifting phase that are highly disturbed and deformed due to subsequent convergence as described above. During this convergence, the Kurnool Supergroup of rocks of Neoproterozoic period was deposited that are undisturbed.

\section{Conclusions: Convergence and Rifting Models of Indian Cratons}

The suggested sequences of events for the formation of the Indian Shield due to interaction of various cratons based on the study as described above are summarized below.

1) Archean cratons converged during Neoarchean-Paleoproterozoic period across the shear zone-Closepet granite between the EDC and the WDC and across the transition zone and the MBSZ between the EDC, the WDC, and the SGT, respectively (Figure 3). This convergence and subduction was primarily $\mathrm{E}-\mathrm{W}$ between the EDC and the WDC giving rise to schist belts with bi- modal volcanic of the WDC and N-S between the WDC and the EDC and the SGT that gave rise to high grade rocks of the SGT due to thrusting. This indicates primary stress direction during this period as NE-SW causing oblique convergence with $\mathrm{N}-\mathrm{S}$ and $\mathrm{E}-\mathrm{W}$ components (Figure 1) that is supported from the predominant NWSE oriented structural trends of the Indian Peninsular shield. It has given rise to thick crust $(>50 \mathrm{~km})$ under the southern part of the WDC and the adjoining western part of the SGT forming crustal root in this section of the Indian shield that are associated with the convergent margins world over as discussed above.

2) The shear zone-Closepet granite, the eastern part of the transition zone (Palar shear) and the MBSZ towards the west are characterized by gravity highs that join around present day Banglore to form a triple junction of this time.

3) During Meso-Neoproterozoic period, NE-SW directed convergence and collision of Bundelkhand craton and Dharwar-Bhandara-Singhbhum cratons in Central India towards south and Rajasthan block towards the west occurred across an arcuate shaped collision zone formed by the SMB and the ADMB. Its N-S and E-W components gave rise to contemporary felsic intrusives similar to island arcs of Bhandara-Bastar and Singhbhum cratons towards south of the SMB (Table 1) and felsic intrusive and back arc basins across the ADMB (Table 1), respectively. The contemporary Upper Vindhyan sediments $(\sim 1.1 \mathrm{Ga})$ along the SMB and the ADMB formed as foreland basin during this convergence. There was a convergence across the GPB almost same time and direction as in case of the SMB and the ADMB (NE-SW) between the Bhandara-Bastar craton and the Dharwar craton towards the west that might be related to latter and gave rise to Bhopalpatnam granulite belt $(\sim 1.6 \mathrm{Ga})$. The gravity anomalies of the Central and the Western parts of the SMB join with those of the GPB to form a triple junction.

4) The above event is preceded by rifting in Central India during Paleo-Mesoproterozoic period ( 1.9 - 1.6 $\mathrm{Ga})$ that gave rise to Mahakoshal and Bijawar Supergroup of rocks with large scale mafic intrusive and Lower Vindhyan sediments $(\sim 1.7 \mathrm{Ga})$ along the SMB and equivalent rocks and contemporary Aravalli Supergroup of rocks along the ADMB over the rifted margins of the Bundelkhand craton (Figure 7, Table 1). The contemporary magmatic rocks of this region may be associated with this rifting phase. Simultaneously, there was a rifting along the GPB providing rifted platform for deposit of Pakhal group of rocks of Paleoproterozoic period. These groups of rocks are associated with large-scale mafic/ultramafic intrusive that is typical of rifting. 
5) Simultaneous to Mesoproterozoic convergence across the ADMB and the SMB, there was a NE-SW to $\mathrm{E}-\mathrm{W}$ convergence across the EGMB between the East Antarctica and the Indian shield (Figure 11) that gave rise to contemporary thrusted rocks of the EGMB and other deep seated intrusive that formed the Grenvillian agglomeration of Indian cratons and East Antarctica. NE-SW oriented shear zones and strike slip motion along them indicates that this convergence also might have been in NE-SW direction as in the previous cases.

6) Prior to this Mesoproterozoic convergence across the EGMB, there was a rifting phase during PaleoMesoproterozoic period $(\sim 1.9-1.5 \mathrm{Ga})$ that gave rise to large scale magmatism of Cuddapah basin and adjoining Bastar craton and Kondapalli layered complex ( 1.7 Ga) of the EGMB that apparently was responsible for the break up of Dharwar craton providing rifted platform for the formation of the several Proterozoic basins along the EGMB including the Cuddapah Super group of rocks. This break up might be related to the break up of Supercontinent Columbia agglomeration in this section due to a plume that existed almost at the same time [68]. In fact, the same plume might have been wide spread that rifted the Indian cratons along the SMB, the ADMB and the GPB during the same period which also show contemporary mafic/ultra mafic intrusive and contemporary basins were formed on rifted platform of cratons along these mobile belts as discussed above. Dates provided here for different periods are at the best approximate, as most of the rocks are not dated so far. More over, this is a general scheme and there may be some variations in various stages of these processes in different sections.

7) There are also indications of a Paleoproterozoic convergence across the EGMB, the SMB, the ADMB and the GPB almost in the same direction (NE-SW) prior to the above rifting $(>1.9 \mathrm{Ga}$ ). Such a process across the EGMB would explain the formation of the Nellore and other schist belts of the EDC and related mafic and felsic

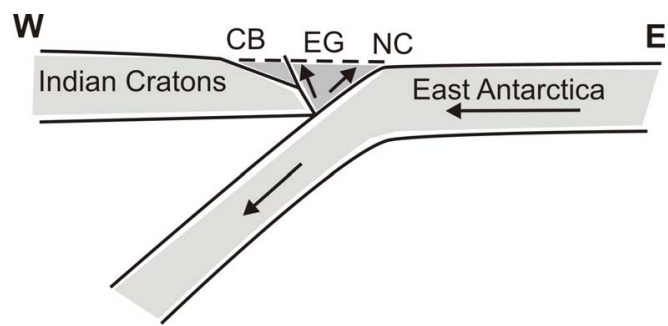

Figure 11. A schematic section of the Mesoproterozoic collision between the Indian cratons and East Antarctica along the EGMB that gave rise to this mobile belt and associated intrusive that gave rise to Cuddapah basin. E-W arrows indicate direction of convergence while opposite arrows indicate direction of thrusting. $\mathrm{CB}$-Cuddapah Basin, EG-Eastern Ghat Mobile Belt, NC-Napier Complex. intrusive. It will also explains the Karimnagar granulite belt (2.4 - 2.2 Ga) across the GPB and various felsic intrusive such as Dongargarh, Malanjkhand and Singhbhum granite plutons across the SMB and Berach granite across the ADMB (Table 1). However, signatures of this convergence are not very clear.

8) In general the present study suggests repeated formation of agglomeration of Indian cratons and East Antarctica and their break up during Paleoproterozoic period (1.9 - $1.6 \mathrm{Ga}$ ) due to a plume followed by a NE-SW convergence during Meso-Neoproterozoic period. This convergence might have driven the other Indian cratons to converge and collide as their movements during this period were in same direction (Figure 1). In general, such repeated formations of Supercontinents and their break up during Neoarchean-Proterozoic period (2.7 - 1.0 Ga) have been suggested by Ernst [69].

9) Signatures of platform deposits and foreland basins are absent from Archean collision zones indicating that they may represent the differences between the Proterozoic and the Archean convergence and collision. The other difference lies in their elevation. Proterozoic fold belts are still observed as high lands while those of Archean period are mostly peneplained plateaus with small variations in elevation and amalgamated to the adjoining cratons.

\section{Acknowledgements}

Author is thankful to The Director, N.G.R.I and CSIR for Emeritus Scientist Scheme and to the Ministry of Earth Sciences for the project, MoES/PO(Seismo)/23(646)/ 2007. Thanks are also due to Mr M. Ravi Kumar for his help towards preparation of the manuscript.

\section{References}

[1] R. A. Gibbs and M. D. Thomas, "Gravity Signature of Fossil Plate Boundaries in the Canadian Shield,” Nature, Vol. 262, No. 5565, 1976, pp. 199-200. doi:10.1038/262199a0

[2] D. M. Fountain and M. H. Salisbury, "Exposed Cross Section through the Continental Crust: Implications for Crustal Structure, Petrology and Evolution,” Earth and Planetary Science Letters, Vol.56, 1981, pp. 263-277. doi:10.1016/0012-821X(81)90133-3

[3] D. C. Mishra, "Building Blocks and Crustal Architecture of Indian Peninsular Shield Cratons and Fold Belts and Their Interaction Based on Geophysical Data Integrated with Geological Information,” Journal Geological Society of India, Vol. 68, No. 6, 2006, pp. 1037-1057.

[4] GSI-NGRI, “Gravity Map Series of India” Geological Survey of India and National Geophysical Research Institute, Hyderabad, 2006. 
[5] D. C. Mishra, B. Singh and V. M. Tiwari, "Gravity Studies in India," Golden Jubilee, Volume of the Geological Society of India Golden Jubilee Memoir of Geological Society of India, 2008, pp. 329-372.

[6] D. V. Subba Rao, "Resolving Bouguer Anomalies in Continents-A New Approach,” Geophysical Research Letters, Vol. 23, No. 24, 1996, pp. 3543-3546. doi:10.1029/96GL03471

[7] D. C. Mishra and L.B. Pedersen, "Statistical Analysis of Potential Fields from Subsurface Relief," Geoexploration, Vol. 19, No. 4, 1982, pp. 247-265. doi:10.1016/0016-7142(82)90030-8

[8] A. P. Singh, D. C. Mishra and G. Laxman, "Apparent Density Mapping and 3-D Gravity Inversion of Dharwar Crustal Province,” Journal Indian Geophysical Union, Vol. 7, No. 1, 2003, pp. 1-9.

[9] M. Jayananda, J. F.Moyan, H. Martin, J. J. Peucat, B. Auvray and B. Mahabaleshwar, "Late Archean (2550-2520 Ma) Juvenile Magmatism in the Eastern Dharwar Craton, Southern India: Constraints from Geochronology, Nd-Sr Isotopes and Whole Rock Geochemistry,” Precambrian Research, Vol. 99, No. 3-4, 2000,pp. 225-254. doi:10.1016/S0301-9268(99)00063-7

[10] D. C. Mishra and S. K. Prajapati, "A Plausible Model for Evolution of Schist Belts and Granite Plutons of Dharwar craton, India and Madagascar during 3.0-2.5 Ga: Insight from Gravity Modelling Constrained in Part from Seismic Studies," Gondwana Research, Vol. 6, No. 3, 2003, pp. 501-511. doi:10.1016/S1342-937X(05)71001-7

[11] B. Chadwick, V. N. Vasudev, G. V. Hegde and A. P. Nutman, "Structure and SHRIMP U/Pb Zircon Ages of Granites Adjacent to the Chitradurga Schist Belt: Implications for Neoarchean Convergence in the Dharwar Craton, Southern India,” Journal Geological Society of India, Vol. 69, 2007, pp. 5-24.

[12] A. Kumar, Y. J. Bhaskar Rao, T. V. Sivaraman and K. Gopalan, "Sm-Nd Ages of Archean Meta-Volcanics of the Dharwar Craton, South India," Precambrian Research, Vol. 80, No. 3-4, 1996, pp. 205-216. doi:10.1016/S0301-9268(96)00015-0

[13] K. Arora, R. P. Rajasekhar and D. C. Mishra, "Density Models of Crust under Dharwar-Granite Greenstone Terrain and the Satpura Mobile Belt: Archean-Proterozoic Analogue of Plate Tectonics," Memoir Gondwana Research, Vol. 10, 2007, pp. 217-226.

[14] S. Kiselev, L.Vinnik, S. Oreshin, S. Gupta, S. S. Rai, A. Singh, M. R .Kumar and G. Mohan, "Lithosphere of the Dharwar Craton by Joint Inversion of P and S Receiver Functions,” Geophysical Journal International, Vol. 173, No. 3, 2008, pp. 1106-1118. doi:10.1111/j.1365-246X.2008.03777.x

[15] S. Gupta, S. S. Rai, K. S. Prakasam and D. Srinagesh, "The Nature of the Crust in Southern India: Implications for Precambrian Crustal Evolution,” Geophysical Research Letters, Vol. 30, No. 8, 2003, p. 1419. doi:10.1029/2002GL0167

[16] K. L. Kaila, R. K. Chowdhury, P. R. Reddy, V. G.
Krishna, H. Narain, S. I. Subbotin, V. B. Sollogulb, A. V. Chekunov, G. E. Kharetcho, M. A. Lazarenko and T. V. Ilchenko, "Crustal Structure along the Kavali-Udipi Profile in the Indian Peninsular Shield from Deep Seismic Sounding,” Journal of Geological Society of India, Vol. 20, 1979, pp. 307-333.

[17] S. G., Gokaran, G. Gupta and C. K. Rao, "Geoelectric Structure of the Dharwar Craton from Magnetotelluric Studies: Archean Suture Identified along the ChitradurgaGadag Schist Belt,” Geophysical Journal International, Vol. 158, No. 2, 2004, pp. 712-728. doi:10.1111/j.1365-246X.2004.02279.X

[18] Y. J. B. Rao, A. S. Janardhan, T. V. Kumar, B. L. Narayana, A. M. Dayal, B. N. Taylor and T. R. K. Chetty, "Sm-Nd Model Ages and Rb-Sr Isotopic Systematics of Charnockites and Gneisses across the Cauvery Shear Zone, Southern India: Implications for the ArchaeanNeoproterozoic Terranes Boundary in the Southern Granulie Terrain,” Memoir Geological Society of India, Vol. 50, 2003, pp. 297-317.

[19] D. C. Mishra and V. V. Kumar, "Evidence for Proterozoic Collision from Airborne Magnetic and Gravity Studies in Southern Granulite Terrain, India and signatures of Recent Tectonic Activity in the Palghat Gap," Gondwana Research, Vol. 8, No. 1, 2005, pp. 1-12. doi:10.1016/S1342-937X(05)70261-6

[20] E. J. Krogstad, S. Balakrishnan, D. K. Mukhopadhyay, V. Rajamani, G. N. Hanson, "Plate tectonics, 2.5 billion yeas ago: Evidence at Kolar South India,” Science, Vol. 243, No. 4896, 1989, pp. 1337-1340. doi:10.1126/science.243.4896.1337

[21] P. R. Reddy, V. Vijayarao. B. R. Prasad, K. Sain, P. Prasad Rao and P. Khare, "Crustal Seismic Studies along Kuppam-Palani Transect in Southern Granulite Terrain,” Memoir Geological Society of India, Vol. 50, 2003, pp.79-106.

[22] D. C. Mishra, V. Vijai Kumar and R. P. Rajasekhar, "Analysis of Airborne Magnetic and Gravity Anomalies of Peninsular Shield, India Integrated with Seismic and Magnetotelluric Results and Gravity Anomalies of Madagascar, Sri Lanka and East Antarctica," Gondwana Research, Vol. 10, No. 1-2, 2006, pp. 6-17. doi:10.1016/j.gr.2005.11.014

[23] D. Canil, “Canada’s Craton: A Bottoms-Up View,” GSA Today, Vol. 18, 2008, pp. 4-10. doi:10.1130/GSAT01806A.1

[24] S. S. Schmidberger, A. Simonetti, L. M. Heaman, R. A. Creaserand and S. Whiteford, "Lu-Hf, in Situ Sr and $\mathrm{Pb}$ Isotope and Trace Element Systematics for Mantle Eclogites from the Diavik Diamond Mine: Evidence for Paleo Proterozoic Subduction Beneath the Slave Craton," Earth and Planetary Science Letters, Vol. 254, No. 1-2, 2007, pp. 55-68. doi:10.1016/j.epsl.2006.11.020

[25] M. Santosh, S. Maruyama and K. Sato, “Anatomy of a Cambrian Suture in Gondwana: Pacific Type Orogeny in Southern India," Gondwana Research, Vol. 16, No. 2, 2009, pp.321-341. doi:10.1016/j.gr.2008.12.012

[26] K. Naganjaneyulu and M. Santosh, “The Cambrian Colli- 
sional Suture of Gondwana in Southern India: A Geophysical Appraisal," Journal of Geodynamics, Vol. 50, No. 3-4, 2010, pp. 256-267. doi:10.1016/j.jog.2009.12.001

[27] U. Raval and K. Veeraswamy, "Within and beyond the Protocontinents: Some Geophysical Aspects Reflecting Geodynamics of the Indian Continental Lithosphere," Memoir Gondwana Research, Vol. 10, 2007, pp. 263285.

[28] GSI, "Geological Map of India on 1: 5 Million Scale,” Geological Survey of India, Calcatta, 1993.

[29] D. H. Yedekar, S. C. Jain, K. K. K. Nair and K. K. Dutta, "The Central Indian Collision Suture. In: Precambrian of Central India," Geological Survey of India, Special Publication, Nagpur, Vol. 28, 1990, pp. 1-43.

[30] S. Sinha-Roy, "Proterozoic Wilson Cycle in Rajasthan," Memoir Gological Society of India, Vol. 7, 1988, pp. 95108.

[31] D. C. Mishra, B. Singh, V. M. Tiwari S. B. Gupta and M. B. S. V. Rao, "Two Cases of Continental Collisions and Related Tectonics during the Proterozoic Period In India-Insights from Gravity Modelling Constrained by Seismic and Magnetotelluric Studies," Precambrian Research, Vol. 99, No. 3-4, 2000, pp. 149-169. doi:10.1016/S0301-9268(99)00037-6

[32] A. P. Singh, D. C. Mishra, V. V. Kumar and M. B. S. V. Rao, "Gravity-Magnetic Signatures and Crustal Architecture along Kuppam-Palani Geotransect, South India”. Memoir Geological Society of India, Vol. 50, 2003, pp. 139-163.

[33] P. R. Reddy, P. R. K. Murthy Rao, I. B. P. D. M. Mall and P. Koteshwar Rao, "Coincident Deep Seismic Reflection and Refraction Profiling of Central India," Research Highlights in Earth System Science, DST Special Volume 1, Indian Geological Congress, 2000, pp. 49-53.

[34] R. P. Rajasekhar and D. C. Mishra, "Crustal Structure of Bengal Basin and Shillong Plateau: Extension of Eastern Ghat and Satpura Mobile Belts to Himalayan Fronts and Seismotectonics," Gondwana Research, Vol. 14, No. 3, 2008, pp. 523-534. doi:10.1016/j.gr.2007.10.009

[35] D. C. Mishra and R. P. Rajasekhar, "Gravity and Magnetic Signatures of Proterozoic Rifted Margins: Bundelkhand Craton and Bijawar and Mahakoshal Group of Rocks and Vindhyan Basin and Their Extension under Ganga Basin,” Journal of Geological Society of India, Vol. 71, 2008, pp. 377-387.

[36] K. Sain, N. Bruguier, A. S. N. Murthy and P. R. Reddy, "Shallow Velocity Structure along Hirapur-Mandla Profile Using Travel Time Inversion of Wide Angle Seismic Data and Its Tectonic Implications,” Geophysical Journal International, Vol. 142, No. 2, 2000, pp. 505-515. doi:10.1046/j.1365-246x.2000.00176.x

[37] J. S. Ray, J. Veizer, W. J. Davis, “C, O, Sr and Pb Isotope systematics of Carbonate Sequences of the Vindhyan Supergroup, India: Age, Diagenesis, Correlations and Implications for Global Events,” Precambrian Research, Vol. 121, No. 1-2, 2003, pp. 103-140.

\section{doi:10.1016/S0301-9268(02)00223-1}

[38] J. S. Ray, M. W. Martin, J. Veizer and S. A. Bowring, "U-Pb Zircon Dating and Sr Isotope Systematics of the Vindhyan Supergroup, India,” Geology, Vol. 30, No. 2, 2002, pp. 131-134. doi:10.1130/0091-7613(2002)030<0131:UPZDAS >2.0.C O;2

[39] D. C. Mishra, "Long hiatus in Proterozoic Sedimentation in India: Vindhyan, Cuddapah and Pakhal Basins-A Plate Tectonics Model," Journal of Geological Society of India, Vol. 77, No. 1, 2011, pp. 17-25. doi:10.1007/s12594-011-0004-9

[40] D. C. Mishra, "Gravity and Magnetic Methods for Geological Studies (Principles Integrated Exploration and Plate Tectonics),” B. S. Publications, Hyderabad \& CRC Press, Boca Raton, 2011, pp. 1-938.

[41] A. Roy and M. H. Prasad, "Tectonothermal Events in Central Indian Tectonic Zone (CITZ) and Its Implications in Rodinian Crustal Assembly," Journal of Asian Earth Sciences, Vol. 22, No. 2, 2003, pp. 115-129. doi:10.1016/S1367-9120(02)00180-3

[42] K. Naganjaneyulu and M. Santosh, "The Central India Tectonic Zone: A Geophysical Perspective on Continental Amalgamation along a Meso Proterozoic Suture,” Gondwana Research, Vol. 18, No. 4, 2010, pp. 547-564, doi:10.1016/j.gr.2010.02.017

[43] S. Majumder and M. A. Mamtani, "Magnetic Fabric in the Malanjkhand Granite (Central India) - Implications for regional Tectonics and Proterozoic Suturing of the Indian Shield,” Physics of the Earth and Planetary Interiors, Vol. 172, No. 3-4, 2009, pp. 310-323. doi:10.1016/j.pepi.2008.10.007

[44] A. R. Sridhar, H. C. Tewari, V. Vijaya Rao, N. Satavani, N. K. Thakur, "Crustal Velocity Structure of the Narmada Son Lineament along the Thuadara-Sendhwa-Sindad profile in the NW Part of Central India and Its Geodynamic Implications,” Journal Geological Society of India, Vol. 69, 2007, pp. 1147-1160.

[45] C. K. Rao, S. G. Gokaran and B. P. Singh, "Upper Crustal Structure in the Torni-Purnad Region, Central India Using Magnetotelluric Studies,” Journal Geomagnetism and Geoelectricity, Vol. 47, No. 4, 1995, pp. 411420. doi:10.5636/jgg.47.411

[46] P. K. Patro and S. V. S. Sarma, "Lithospheric Electrical Imaging of the Deccan Trap Covered Region of Western India,” Journal of Geophysical Research, Vol. 114, 2009, pp. B01102-B01118. doi:10.1029/2007JB005572

[47] S. A. Chore and M. Mohanty, "Stratigraphy and Tectonic Setting of the Trans Aravalli, Neoproterozoic Volcano Sedimentary Sequence in Rajasthan,” Journal Geological Society of India, Vol. 51, 1998, pp. 57-68.

[48] B. V. Lente, L. D. Ashwal, M. K. Pandit, S. A. Bowring and T. H. Torsvik, "Neoproterozoic Hydrothermally Altered Basaltic Rocks from Rajasthan, Northwest India: Implications for Late Precambrian Tectonic Evolution of the Aravalli Craton,” Precambrian Research, Vol. 170, No. 3-4, 2009, pp. 202-222. 
doi:10.1016/j.precamres.2009.01.007

[49] P. S. R. Raju, "Geology and Hydrocarbon Prospects of Pranhita-Godavari Graben,” Journal of Association of Exploration Geophysics, Vol. 7, No. 3, 1986, pp. 131146.

[50] T. S. Rao, "The Pakhal Basin; A perspective. In: Purana Basins of Peninsular India, Middle to Late Proterozoic Based on the Proceedings of the Seminar," Memoir Geological Society of India, Vol. 6, 1987, pp. 161-187.

[51] M. Santosh, K. Yokoyama and S. K. Acharyya, "Geochronology and Tectonic Evolution of Karimnagar and Bhopalpatnam Granulite Belts, Central India,” Gondwana Research, Vol. 7, No. 2, 2004, pp. 501-518. doi:10.1016/S1342-937X(05)70801-7

[52] J. M. Rao, G. V. S. P Rao and S. K. Patil, "Geochemical and Paleomagnetic Studies on the Middle Proterozoic Karimnagar Mafic Dyke Swarm, India,” In: A. P. Parker, P. C. Rock Wood and D. H. Tucker, A. A. Balkema, Eds., Rotterdam Mafic Dykes and Emplacement Mechanism, Balkema, Rotterdam, 1990, pp. 373-382.

[53] K. L. Kaila, P. R. K. Murthy, V. K. Rao and N. Venkateswarlu, "Deep Seismic Sounding in the Godavari Graben and Godavari (Coastal) Basin, India,” Tectonophysics, Vol. 173, 1990, pp. 307-317. doi:10.1016/0040-1951(90)90226-X

[54] D. C. Mishra, "Paleomagnetism of variation Rocks of India,” Ph.D. Thesis, Banaras Hindu university, Banaras, 1965,

[55] K. Mezger and M. A. Cosca, "The Thermal History of the Eastern Ghats Belts (India) as Revealed by U-Pb and (super 40) Ar/(Super 39) A Dating of Metamorphic and Magmatic Minerals: Implications for the SWEAT Correlation,” Precambrian Research, Vol. 94, No. 3-4, 1999, pp. 251-271. doi:10.1016/S0301-9268(98)00118-1

[56] D. K. Paul, T. Barman, N. J. McNaughton, I. R. Flecther, P. J. Potts, M. Ramakrishnan and P. F. Augustine, "Archean-Proterozoic Evolution of Indian Charnockites-IsoTopes and Geochemical Evidence from Granulites of the Eastern Ghat Belt,” Journal of Geology, Vol. 98, No. 2, 1990, pp. 253-263. doi:10.1086/629396

[57] C. J. Dobmeier and M. Raith, "Crustal Architecture and Evolution of the Eastern Ghats Belt and Adjacent Regions of India,” In: M. Yoshida, B. F. Windley, S. Dasgupta, Eds., Proterozoic East Gondwana: Super continent Assembly and Break up, Geological Society, Special Publications, London, Vol. 206, 2003, pp. 145-168.

[58] S. K. Acharyya, “A Plate Tectonic Model for Proterozoic Crustal Evolution of Central Indian Tectonic Zone, Gond,” Geological Magazine, Vol. 7, 2003, pp. 9-31.

[59] C. J. Dobmeier, S. Lutke, K. Hammerschmidt and K. Mezger, "Emplacement and Deformation of the Vinukonda Meta-Granite (Eastern Ghats, India: Implications for the Geological Evolution of Peninsular India and for Rodinia Reconstructions," Precambrian Research, Vol. 146, No. 3-4, 2006, pp. 165-178. doi:10.1016/j.precamres.2006.01.011

[60] K. V. Kumar and C. Leelanandam, "Evolution of the Eastern Ghats Belt, India: A Plate Tectonic Perspective,” Journal of the Geological Society of India, Vol. 72, No. 6, 2008, pp. 720-759.

[61] B. K. Nagaraja Rao, S. T. Rajurkar, G. Ramlingaswamy and B. R. Babu, "Stratigraphy, Structure and Evolution of the Cuddapah Basin," Memoir Geological Society of India, Vol. 6, 1987, pp. 33-87.

[62] J. E. French, L. M. Heaman, T. Chacko and R. K. Srivastava, "1891-1883 Ma Southern Bastar-Cuddapah Mafic Igneous Event, India: A Newly Recognized Large Igneous Province,” Precambrian Research, Vol. 160, No. 3-4, 2008, pp. 308-322. doi:10.1016/j.precamres.2007.08.005

[63] V. B. Rao, Y. Sreedhar Murthy and K. Govindarajan, "Contours to Images-Part II: Aeromagnetic Image of Western Part of Cuddapah Basin and Adjoining Crystallines-A Case Study,” Journal of Geophysics, Vol. 19, 1998, pp. 195-203.

[64] D. C. Mishra, V. Babu Rao, G. Laxman, M. B. S. V. Rao and M. Venkatarayudu, "Three-Dimensional Structural Model of Cuddapah Basin and Adjacent Eastern Part from Geophysical Studies,” Memoir Geological Society of India, Vol. 6, 1987, pp. 313-330.

[65] K. Naganjaneyulu and T. Harinarayana, "Deep Crustal Electrical Signatures of Eastern Dharwar Craton, India,” Gondwana Research, Vol. 7, No. 4, 2004, pp. 951-960. doi:10.1016/S1342-937X(05)71077-7

[66] D. C. Mishra and V. M. Tiwari, “An Asymmetrical Basic Lopolith below Sediments in Western Cuddapah Basin-Geophysical evidence, Proc. Annual Convention of Geological Society of India," University of Tirupati, Tirupati, 1995, 31-41.

[67] T. R. K. Chetty, "The Eastern Ghats Mobile Belt, India: A Collage of Juxtaposed Terranes (?)," Gondwana Reseach, Vol. 4, No. 3, 2001, pp. 319-328. doi:10.1016/S1342-937X(05)70332-4

[68] J. J. W. Rogers and M. Santosh, "Tectonics and Surface Effects of the Supercontinent Columbia," Gondwana Research, Vol. 15, No. 3-4, 2009, pp. 373-380. doi:10.1016/j.gr.2008.06.008

[69] W. G. Ernst, “Archean Plate Tectonics, Rise of Proterozoic Supercontinentality and Onset of Regional, Episodic Stagnant-Lid Behavior,” Gondwana Research, Vol. 15, No. 3-4, 2009, pp. 243-253. doi:10.1016/j.gr.2008.06.010

[70] S. N. Sarkar, K. Gopalan and J. R. Trivedi, "New Data on the Geochronology of the Precambrians of Bhandara-Drug, Central India,” Indian Journal of Earth Science, Vol. 8, No. 2, 1981, pp. 131-151. 